\title{
Characterization of SNP1, a Cell Wall-Degrading Trypsin, Produced During Infection by Stagonospora nodorum
}

\author{
A. J. Carlile, ${ }^{1}$ L. V. Bindschedler, ${ }^{1}$ A. M. Bailey, ${ }^{2}$ P. Bowyer ${ }^{3}$ J. M. Clarkson, ${ }^{1}$ and R. M. Cooper ${ }^{1}$ \\ ${ }^{1}$ Microbial Pathogenicity Group, Department of Biology and Biochemistry, University of Bath, Claverton \\ Down, BA2 7AY, U.K.; ' School of Biological Sciences, University of Bristol, Woodland Rd., Bristol, U.K.; \\ ${ }^{3}$ Cell Biology Department, IACR Long Ashton Research Station, Bristol BS18 9AF, U.K. \\ Accepted 25 January 2000.
}

\begin{abstract}
Stagonospora (= Septoria) nodorum when grown in liquid culture with wheat cell walls as the sole carbon and nitrogen source secretes numerous extracellular depolymerases, including a rapidly produced, alkaline, trypsinlike protease (SNP1). The enzyme was purified 417 -fold by cation exchange chromatography and has a molecular mass of $25 \mathrm{kDa}$ on sodium dodecyl sulfate gels, pI 8.7, and pH optimum of 8.5. It cleaved peptide bonds on the carboxyl side of lysine or arginine, was strongly inhibited by the trypsin inhibitors aprotinin and leupeptin and weakly by phenylmethylsulfonyl fluoride, and its activity was stimulated by calcium. SNP1 has the characteristic, conserved, fungal, trypsin $\mathrm{N}$ terminus. Polymerase chain reaction (PCR) primers based on this sequence and the conserved trypsin active site were used to amplify a DNA fragment that facilitated isolation of the corresponding genomic clone from a lambda library of $S$. nodorum. The full-length sequence confirmed its identity as a trypsin-like protease containing the $\mathrm{N}$-terminal sequence of the previously purified enzyme. Infected leaf tissue contained a protease, not present in controls, that coeluted with the fungal trypsin from cation exchange, and had properties (pI and inhibitor characteristics) similar to those of the fungal trypsin. SNP1 expression in planta was detected by Northern (RNA) blotting, reverse transcription PCR, and green fluorescent protein confocal microscopy. SNP1 released hydroxyproline from wheat cell walls. The release of hydroxyproline, together with its early expression in planta, suggests that SNP1 participates in the degradation of host cell walls during infection.
\end{abstract}

Additional keywords: cell wall proteins, plant pathogen, virulence.

Stagonospora nodorum causes a leaf and glume blotch of wheat (Weber 1922). Despite the widespread and economic impact of this necrotrophic pathogen (King et al. 1983), very little is known about how it causes disease. Extensive epi-

Corresponding author: R. M. Cooper; Telephone: 0122532 3051; Fax: 0122582 6779; E-mail: R.M.Cooper@bath.ac.uk

Nucleotide and/or amino acid sequence data for Snpl can be found at the GenBank data base as accession no. AF092435. phytic growth precedes penetration and then subcuticular, lateral growth occurs within the epidermal wall. Subsequent invasion of the mesophyll involves sparse intercellular growth with occasional cell wall penetration and collapse of surrounding cells (Karjalainen and Lounatmaa 1986; Bird and Ride 1981; Zinkernagel et al. 1988). Regions beneath penetration sites are more diffuse than the normal wall (Karjalainen and Lounatmaa 1986). Overall, this evidence suggests a possible role for cell wall-degrading enzymes in penetration and colonization.

A direct involvement for cell wall-degrading enzymes in infection by $S$. nodorum has not been established but their production both in vitro (Lehtinen 1993; Magro 1984) and in vivo (Magro 1984) has been detected. Both of these studies focused largely on polysaccharide-degrading enzymes, the major activities of which reflected the composition of the wheat cell wall, in which arabinoxylan is a key matrix component (Carpita and Gibeaut 1993). Given that the cell walldegrading enzymes produced by plant pathogens are adapted to their host cell walls (Cooper et al. 1988), it is surprising that one class of enzymes often overlooked are proteases. In some plant species proteins can account for up to $15 \%$ of the cell wall, where they serve both structural and enzymatic functions (Showalter 1993). There are five major classes of cell wall proteins mostly characterized from advanced dicots. These are extensins (hydroxyproline-rich glycoproteins, HRGPs), glycine-rich proteins (GRPs), proline-rich proteins (PRPs), arabino-galactan proteins (AGPs), and solanaceous lectins. Some have been found in different forms in graminaceous monocots such as threonine-hydroxyproline-rich glycoproteins (THRGPs) and a histidine-rich form (HHRGPs) (Kieliszewski et al. 1989; Showalter 1993). HRGPs can be produced at elevated levels during pathogenesis (Clarke et al. 1981; Mazau and Esquerré-Tugayé 1986). If invading fungi can degrade these proteins, proteases may play an important role as virulence factors. Proteases may also counter host defense-related proteins, such as the antifungal enzymes chitinases and glucanases (Mauch et al. 1988). Proteases can be involved in processing fungal toxins (Howard and Buckley 1985), elicitors (van den Ackerveken et al. 1993), and zymogens (Rypniewski et al. 1994). Alternatively they may be toxic per se by their action on host cell walls (Movahedi and Heale 1990b) or on the host plasma membrane (Tseng and 
Mount 1974), or they may disrupt cortical microtubules by degrading a linked transmembrane-extensin system (Akashi and Shibaoka 1991). Proteases may also serve a nutritional role, e.g., in the interaction between the endophyte Acremonium typhinum and its host grass (Lindstrom and Belanger 1994). The production of protease inhibitors by many plants, including monocots and the demonstration that they can affect fungal pathogens (Joshi et al. 1998; Koiwa et al. 1997; Lorito et al. 1994) suggest that there is a need for plants to defend themselves against pathogen proteases. Moreover, the induction of a protease inhibitor during the incompatible interaction between $S$. nodorum and barley (Stevens et al. 1996) strengthens this hypothesis.

Proteases are produced by many plant-pathogenic fungi and bacteria, including the biotrophs Uromyces viciae-fabae (Raucher et al. 1995) and Ustilago maydis (Hellmich and Schauz 1988), the hemibiotrophic Colletotrichum lindemuthianum (Ries and Albersheim 1973), and necrotrophs such as Botrytis cinerea (Movahedi and Heale 1990a). Attempts to establish involvement of proteases in virulence have given conflicting results, such as positive associations for Magnaporthe poae infecting roots of Kentucky bluegrass, Xanthomonas campestris and turnip leaves, and Pyrenopeziza brassicae and oilseed rape (Sreedhar et al. 1999; Dow et al. 1990; Ball et al. 1991); in no case was the cellular function of the protease established. In contrast, protease-defective mutants of Erwinia chrysanthemi, Cochliobolus heterostrophus, $C$. carbonum, and Cladosporium cucumerinum were unaffected in pathogenicity (Dahler et al. 1990; Walton 1994; Murphy and Walton 1996; Robertson 1984).

Here we report the purification, characterization, and sequence of an alkaline, trypsin-like, extracellular protease produced by $S$. nodorum when grown on wheat cell walls, its detection in planta during infection, and its ability to degrade wheat cell walls. The putative roles of a trypsin-like protease, SNP1 ( $\underline{S}$. nodorum protease $\underline{1})$, as a cell wall-degrading enzyme and as a virulence factor are discussed.

\section{RESULTS}

When $S$. nodorum was grown in liquid culture on wheat cell walls a number of different extracellular depolymerases were produced. Major activities were xylanase and $\beta$ 1-3 glucanase, both detectable $12 \mathrm{~h}$ after transfer onto cell walls and peaking at 24 and $72 \mathrm{~h}$, respectively. High protease activity was detected with the general protease substrate azocasein at $12 \mathrm{~h}$ and maximum production was at $24 \mathrm{~h}$. Preliminary studies in vivo also showed elevated levels of protease activity in infected plants, compared with controls, throughout (2 to 14 days) infection. The only other putative fungal enzyme activities clearly detected in planta were xylanase (confirmed as $S$. nodorum xylanase by Western blotting [immunoblotting]) and arabinosidase, but these activities were associated with later stages (>3 to 4 days) of lesion development (data not shown). Therefore, our initial research centered on $S$. nodorum protease(s).

\section{Purification of SNP1.}

Isoelectric-focusing gelatin overlays of crude culture fluids showed a single major protease activity with a $\mathrm{pI}$ of approximately 8.7. Purification was achieved by two steps of cation exchange chromatography. The first round of cation exchange chromatography (SP Sepharose) was performed on fast protein liquid chromatography (FPLC). Figure 1A shows a typical profile; peak protease activity was subjected to high resolution cation exchange separation by perfusion chromatography. Peak activity in four fractions appeared as a single peak during both steps. Sodium dodecyl sulfate-polyacrylamide gel electrophoresis (SDS-PAGE; Fig. 2) monitored each stage and revealed that peak fractions from the second cation exchange chromatography step contained a major band of $25 \mathrm{kDa}$. The protein content and the activities of the protease at the various stages of the purification procedure are given in Table 1. A 417-fold purification was achieved.
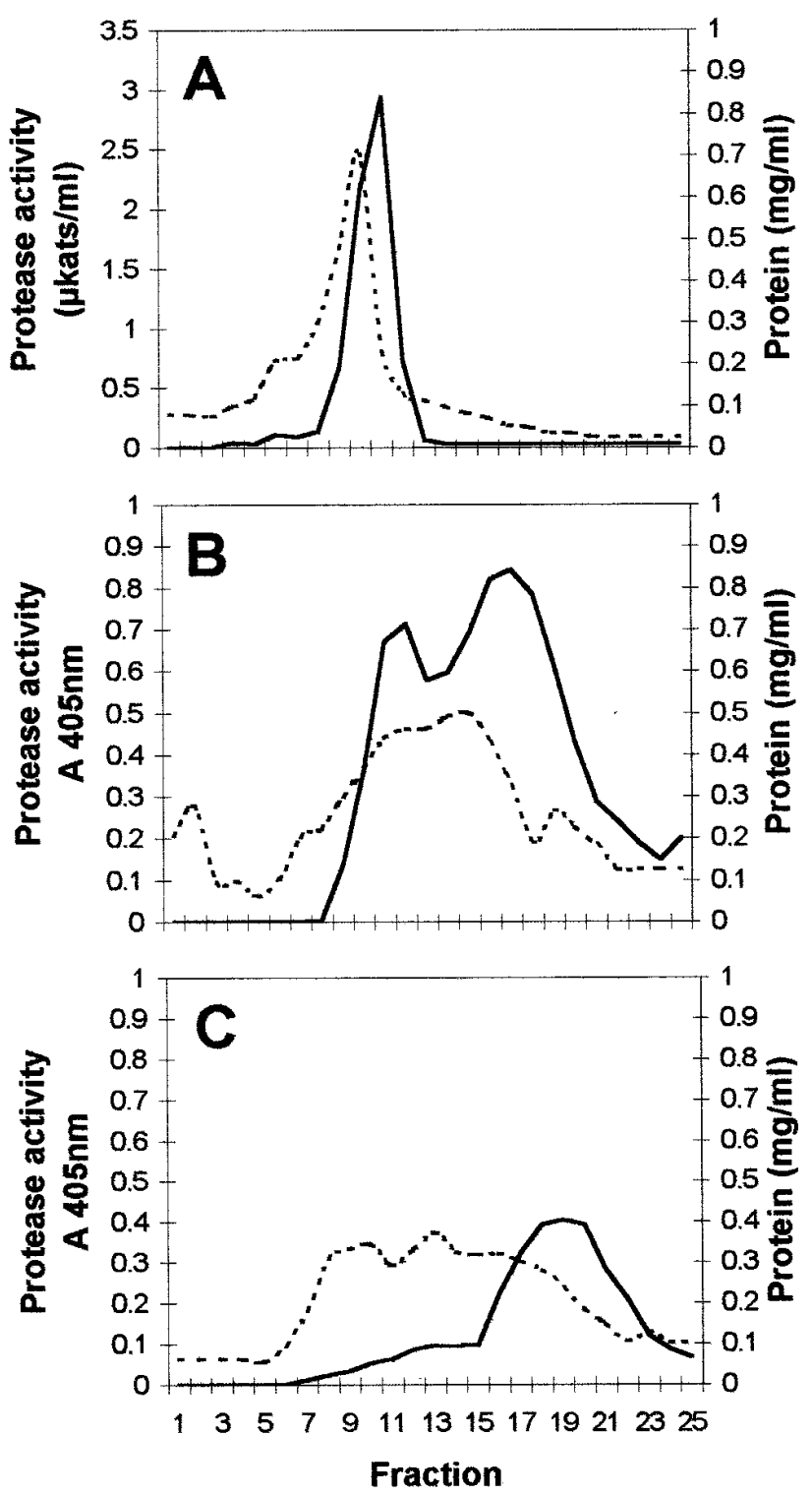

Fig 1. A, Elution profile of SNP1 from an S-Sepharose cation exchange column in $25 \mathrm{mM}$ 2-( $N$-morpholino)ethane sulfonic acid (MES) pH 6.0 eluted over a linear $0-200 \mathrm{mM} \mathrm{NaCl}$ gradient. Elution profiles of (B) infected and (C) control plant protein extracts eluted under the same conditions. Protein $\mathrm{mg} \mathrm{ml}^{-1}$ (----); protease activity (-) is expressed either (A) as $\mu \mathrm{kats} \mathrm{ml}^{-1}$ after the standard 15-min assay or (B,C) as absorbance units following a 12-h assay. All assays were performed with the trypsin substrate Benz-Phe-Val-Arg-NA. 


\section{N-terminal sequence.}

Peak fractions from the perfusion chromatography step were run on SDS-PAGE, blotted onto polyvinylidene difluoride (PVDF) membrane and stained as described by Packman (1993). N-terminal sequencing of the $25-\mathrm{kDa}$ band (underlined sequence in Figure 3) revealed it to be a trypsin-like protease showing $89.5 \%$ identity with a trypsin protease from Fusarium oxysporum (Rypniewski et al. 1993) and 84.2\% identity with ALP1 of Cochliobolus carbonum (Murphy and Walton 1996) over the 19 amino acids determined.

\section{Temperature and pH optima.}

SNP1 has a temperature optimum of $35^{\circ} \mathrm{C}$ but was most stable at $4^{\circ} \mathrm{C}$ after a 1 -h incubation period It has a broad $\mathrm{pH}$ optimum over the range 7 to 9 but activity rapidly declines above and below this. Consistent with this was maximum stability at $\mathrm{pH} 8$ (data not shown).

\section{Metal ions.}

Protease activity was unaffected by the metal ions $\mathrm{MnCl}_{2}$, $\mathrm{MgCl}_{2}, \mathrm{NaCl}, \mathrm{ZnCl}_{2}$, over the range 1.25 to $10 \mathrm{mM}$ or by $\mathrm{PbAc}_{2}$ and $\mathrm{FeCl}_{3}$ over the range 1.25 to $5 \mathrm{mM}$, but was inhibited by 85 and $60 \%$, respectively, at $10 \mathrm{mM}$. Protease activity was stimulated approximately $22 \%$ by calcium ions, optimally at $2.5 \mathrm{mM}$ (data not shown). This calcium re-

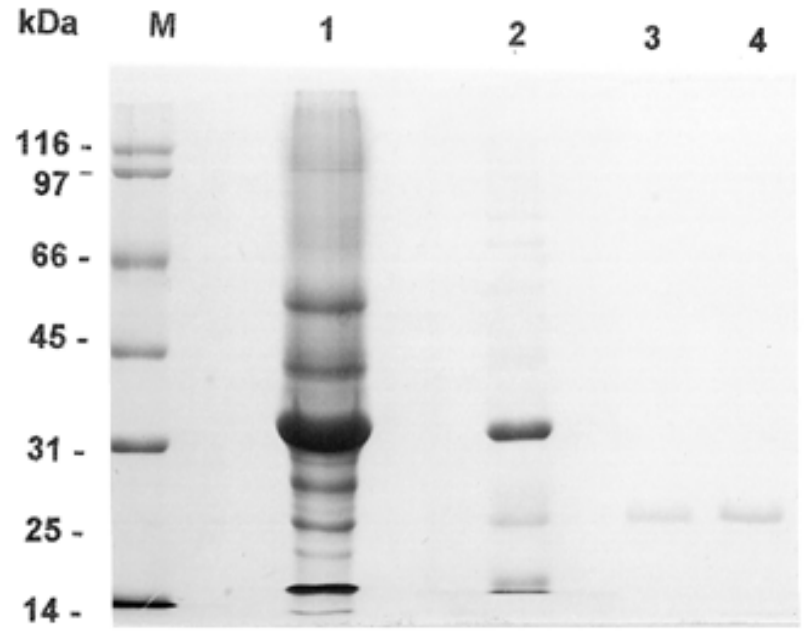

Fig. 2. Sodium dodecyl sulfate-polyacrylamide gel electrophoresis (SDS-PAGE) (12\%) showing purification of the trypsin-like protease secreted by Stagonospora nodorum. M, molecular mass standards expressed in $\mathrm{kDa}$; lane 1, culture filtrate after $48 \mathrm{~h}$ of growth on wheat cell walls; lane 2, proteins from fast protein liquid chromatography (FPLC) cation exchange chromatography fractions showing peak protease activity; lanes 3 and 4, 25-kDa protein from BioCad HS20 cation exchange chromatography showing peak protease activity. quirement is consistent with the enzyme being a trypsin-like protease.

\section{Inhibitors.}

The pure protease (assayed with Benz-Phe-Val-Arg-NA) was classified with the use of standard inhibitors (Fig. 4). The purified protease was strongly inhibited by aprotinin (99\%) and leupeptin (99\%) and weakly inhibited by phenylmethylsulfonyl fluoride (PMSF; 30\%), characteristic of trypsin-like proteases (Gebhard et al. 1986; Powers and Harper 1986). Soybean trypsin inhibitor and turkey egg white inhibitor also inhibited the protease, with 98 and $90 \%$ inhibition, respectively. EDTA inhibited activity by $20 \%$, consistent with the metal ion requirement of calcium; this also coincided with some loss of activity of protease after extensive dialysis. The cysteine and aspartic inhibitors iodoacetic acid and pepstatin were ineffective against the protease.

\section{Substrate range and kinetics.}

Pure SNP1 was assayed against a range of nitroanilide substrates to assess substrate specificity. It showed no activity against the chymotrypsin substrate Suc-Ala-Ala-Pro-Phe-NA or the subtilisin substrate CBZ-Gly-Gly-Leu-NA.

A kinetic analysis was performed with the pure protease against a range of trypsin nitroanilide substrates and the $\mathrm{K}_{\mathrm{m}}$ and $\mathrm{V}_{\max }$ calculated for each with the direct linear plot (Cornish-Bowden and Eisenthal 1974). The substrate range used was 0.125 to $2 \mathrm{mM}$ with a fixed enzyme amount of 0.02 $\mu \mathrm{g}$ (Table 2).

SNP1 showed a preference for the substrates Benz-Phe-ValArg-NA and D-Val-Leu-Arg-NA. It was least active against Benz-Pro-Phe-Arg-NA but higher activity occurred when Arg was replaced by Lys in the substrate D-Val-Phe-Lys-NA. The ability to cleave at the carboxyl side of both Arg and Lys is indicative of a trypsin-like protease.

\section{Effect of SNP1 on wheat cell walls.}

SNP1 could degrade collagen (based on degradation of azocoll), a hydroxyproline-rich protein, suggesting that this protease may be able to degrade some plant cell wall structural proteins. Two different concentrations of pure SNP1 were used to digest $5 \mathrm{mg}$ of wheat cell walls. With $0.4 \mu \mathrm{g}$ of protein (corresponding to $1.6 \mu \mathrm{kats}$ ) there was no significant degradation of wheat cell walls, compared with controls (Fig. 5). However, $2 \mu \mathrm{g}$ of protein (8 $\mu \mathrm{kats})$ resulted in an approximately 3.5-fold increase in release of hydroxyprolinecontaining proteins from cell walls. This was equivalent to a total of $1.6 \mu \mathrm{g}$ of hydroxyproline, which is approximately $40 \%$ of that present in the wall. The estimate of $0.8 \mu \mathrm{g}$ of hydroxyproline per $\mathrm{mg}$ of cell wall agrees closely with that found in wheat cell walls by Clarke et al. (1981).

Table 1. Purification summary for the isolation of an alkaline protease from the culture filtrate of Stagonospora nodorum ${ }^{\text {a }}$

\begin{tabular}{|c|c|c|c|c|c|c|c|}
\hline Purification step & Protein mg/ml & Volume ml & $\begin{array}{c}\text { Total protein } \\
\text { (mg) }\end{array}$ & $\begin{array}{c}\text { Activity per } \boldsymbol{\mu l} \\
\text { (nkats) }\end{array}$ & $\begin{array}{l}\text { Total activity } \\
\quad(\mu \text { kats })\end{array}$ & $\begin{array}{c}\text { Specific activity } \\
\text { per mg ( } \mu \text { kats) }\end{array}$ & $\begin{array}{c}\text { Purification } \\
\text { (n-fold) }\end{array}$ \\
\hline Culture filtrate* & 0.3 & 100 & 30 & 3 & 300 & 10 & \\
\hline Ammonium sulfate* & 2.5 & 10 & 25 & 30 & 300 & 12 & 1.2 \\
\hline Cation exchange1† & 0.4 & 2.5 & 1 & 46.7 & 116.7 & 117 & 11.7 \\
\hline Cation exchange $2 \dagger$ & 0.004 & 1.5 & $6 \mu \mathrm{g}$ & 16.67 & 25 & 4167 & 417 \\
\hline
\end{tabular}

${ }^{a}$ Protease activity was initially determined on azocasein* then on Benz-Phe-Val-Arg-NA. $\dagger$ 
Addition of the trypsin inhibitor aprotinin at $1 \mu \mathrm{m}$ reduced levels of hydroxyproline release by pure SNP1 to that of controls. This clearly demonstrates that pure SNP1 alone can degrade the wheat cell wall.
Effect of SNP1 on tritordeum suspension cells.

SNP1 activities ranging from 35 nkats to $20 \mu$ kats were assayed for their ability to kill tritordeum (fertile amphidiploid between Hordeum chilense and Triticum durum) suspension
61

121

181

241

301

361

421

481

541

601

661

721

781

841

901

961

1021

1081

1141

1201

1261

1321

1381

1441

1501

1561

1621

1681

1741

1801

1861

1921

1981

2041

2101

2161
GTCGACGGGTGAATTTGCGGGACGGTGTTTCCGTCTCCTGCACGCCTGATCGCGCGATGC GATGCAAAGTGGCACCTGCAAAGAAGCAAAAGGACCGTCTGAGGAGGCATCCGGACAACT CCGACCATCTCGTTCGAATGAAACGCCAGCACGTGATAGACCACAGGACTTGCCTCCTCC CTATTCCTGCCTCATTCCAGTAGCTGTCCAATGCGAGCGGCTGCACTTGAAGTGTCCAAG CCAGCCCGCCTGTGGTGTTTTGAAGATCCCGCCTCCACTGGGCATGATCGCCACCATGGC CCCGGGGCTTGATTGACTACGCTACGCTGATGCCAAGCACCAATGTCTACGTGCAACTGC CTTTCTGGGCGCTGACCCGCTCGCTAAGTCGCATCACGTCACGTCTCCTACACCAACCAC GCGCCGAGGCGTATCTTGTCTCCTGTTACTGCAATATAAGAAAAGCTTGGTATTCTCTTG CCAAGAAGGCAGCGTGAAGATCATTGACCCCACGTCCGATCGCCTACTCCGAGTATGGCA GGTCTGCCTGTTTCATGATTTGTACCACGGTTTGCTCATGGACGTCAACCATGTTATCGC TCTTGATCGACAGTGTTCTAGCATGATTATGCAGTCTACTATACGGCGTGGCCGTCTTCG GCTGCTTTGCCCGCGAAACTTTGCAGATATGTCCGGGAATGGCCGCGCCTACATAGATCT ACACAGGCCTTCTACACTGCACGGCGCCCGAAAGCAGATCTAACACGTCTGATTACACTC GCGAGACCTCGCCACCAGGCCTCACAAGGCAGAAGACGCGGCGCGGGAATTACTCGTGGC TGCGTGAAAGAGGTCGGCAACGAAACAGTTCTGCACTACGCTTAGCATAGCGCCGAAAAG TCTCCTAATATCGGCCGTGGCATTAAGGACTACACGGGAACTAGACGATCCACTTCGCCA ACTTCCTCTTTGGCACTGTCACAGGCTACCCTAGAGCGCGCTTAAGCGACGGCAGATAAG TACCACTTCATCGGAGGCAAGGCACAACATGGACCTACATGTCCCCACTAAGCCAAAGAA GGTACTTGTAACTTTAGCAGCTCCAATCACTTCTCTGCCCAGACGTGATTAGACCCTATC TGGAAGGACCTGATCGTCCCCTGGCCTAATGACCTTCGAGCATCTACGACGACAGGACAG GAAGGTTGATGGACATCAGATGAAGCCATACACCATGTAGCACGCAACTGAAGTACAAAT ATCAGGGCCTCAACCCTCTCTTTGCAAACCAGTCCTTCACTACAACTCTCGCTACAGACA CCTTCCAGCCAGCCAGCTTCAGACCTACCCTCAGCCTCATTCAAGATGCACTTCACAGAC $\begin{array}{llll}M & \mathrm{~F} & \mathrm{~T} & \mathrm{D}\end{array}$ GTCCTCATTGCCCTCGCGGCTCCCGCTCTCATCAGCGCTGCGGCTATCCCCCAGGACCCT $\begin{array}{llllllllllllllllllll}\mathrm{V} & \mathrm{L} & \mathrm{I} & \mathrm{A} & \mathrm{L} & \mathrm{A} & \mathrm{A} & \mathrm{P} & \mathrm{A} & \mathrm{L} & \mathrm{I} & \mathrm{S} & \mathrm{A} & \mathrm{A} & \mathrm{A}^{*} & \mathrm{I} & \mathrm{P} & \mathrm{Q} & \mathrm{D} & \mathrm{P}\end{array}$ GAGTTCCCTGAGGGCGAGTTCCCCGAGGACCCCATCGTTGGCGGAACCACCGCCAGCGCT \begin{tabular}{llllllllllllllllllll}
$E$ & $F$ & $P$ & $E$ & $G$ & $E$ & $F$ & $P$ & $E$ & $D$ & $P$ & $I$ & $V$ & $G$ & $G$ & $T$ & $T$ & $A$ & $S$ & $A$ \\
\hline
\end{tabular} GGCGACTTCCCCTTCATCGTCTCCATCCAGCAGGGCGGAAGCCACTTCTGCGGTGGTTCG $\begin{array}{llllllllllllllllllll}G & D & E & P & F & I & V & S & I & Q & Q & G & G & S & H & F & C & G & G & S\end{array}$ CTGCTGAACGCCAACACCGTCCTGACCGCCGCTCACTGCGCTGTCGGACAGACTGCTTCC $\begin{array}{llllllllllllllllllll}I & L & N & A & N & T & V & L & T & A & A & H & C & A & V & G & Q & T & A & S\end{array}$ AGCCTTCAGATCCGCGCTGGCTCTCTCgtaagacatgccatatt cacCatctcatcCaa $S \quad I \quad Q \quad I \quad R \quad A \quad G \quad S \quad L$ cttcccactaacacccct ccagAGCCGTACCTCCGGCGGAACCGTCGTCAAGGTGTCCT $\begin{array}{llllllllllllllll}S & R & T & S & G & G & T & V & V & K & V & S & S\end{array}$ CCATCAAAGTCAACCCCTCGTACGCCGCCGGCACCTACAACAACGACGTTGCCATCATGA $\begin{array}{llllllllllllllllllll}I & K & V & N & P & S & Y & A & A & G & T & Y & N & N & D & V & A & I & M & K\end{array}$ AGCTCGCCACCTCCATCCCCACCAGCTCCACCATCAGCTACGCCAAGCTCGCCTCTTCTG $\begin{array}{llllllllllllllllllll}L & A & T & S & I & P & T & S & S & T & I & S & Y & A & K & L & A & S & S & G\end{array}$ GCTCCGACCCTGCCGCTGGCACCGGCCTCACCGTCGCCGGCTGGGGCACCACCAGCTCCG $\begin{array}{llllllllllllllllllll}S & D & P & A & A & G & T & G & L & T & V & A & G & W & G & T & T & S & S & G\end{array}$ GCGGCCAGTCCCTGCCCGTCAACCTCCTCAAGGTCGACGTGCCCGTCATCAGCCGCTCCA $\begin{array}{llllllllllllllllllll}G & Q & S & L & P & V & N & L & L & K & V & D & V & P & V & I & S & R & S & T\end{array}$ CTTGCAACTCCAACTACGGCAGCGGACGCATCACGACGGCCATGTTCTGCGCTGGCCTGT $\begin{array}{llllllllllllllllllll}C & N & S & N & Y & G & S & G & R & I & T & T & A & M & F & C & A & G & L & S\end{array}$ CCCAGGGTGGAAAGGACTCGTGCCAGGGTGACTCTGGCGGCCCCATCATCAACACCTCTT $\begin{array}{llllllllllllllllllllllllll}Q & G & G & K & D & S & C & Q & G & D & S & G & G & P & I & I & N & T & S & S\end{array}$ CGCGCGTGCAGGTTGGTGTGGTTTCTTGGGGTGAGGGTTGCGCGTCTGCGGGTGCGCCTG $\begin{array}{llllllllllllllllllll}R & V & Q & V & G & V & V & S & W & G & E & G & C & A & S & A & G & A & P & G\end{array}$ GTGTCTACTCCAACTTGGGCCAGAGCAGCCTTGCGAGCTTTGTTGCTGCCAACTTGTAGA

$\begin{array}{llllllllllllllllll}V & Y & S & N & L & G & Q & S & S & L & A & S & F & V & A & A & N & L\end{array}$
5

25

45

65

85

94

107

127

147

167

187

207

Fig. 3. Sequence of SNP1. The N terminus amino acid sequence (IVGGTTASAGDFPFIVSIQ) obtained directly from the mature protein SNP1 is indicated by underlining. Active site sequence, conserved among other trypsin-like proteases, CQGDSGGP, used to design the second oligonucleotide primer for polymerase chain reaction (PCR) amplification is also indicated by underlining. Intron is indicated in lowercase letters; putative signal peptide cleavage site is indicated by *. 
cells. None of the concentrations tested affected viability, compared with controls, after $48 \mathrm{~h}$ (data not shown). Therefore, no direct, phytotoxic effect could be assigned to SNP1.

\section{Isolation and characterization of SNP1.}

Degenerate primers based on the N-terminal amino acid sequence IVGGTTA and the active site conserved sequence CQGDSGGP were used to amplify a single 610-bp polymerase chain reaction (PCR) product from genomic $S$. nodorum DNA. The sequence of this fragment, which encodes the SNP1 N terminus, was highly similar to that of trypsinlike proteases (data not shown). The PCR product contained an open reading frame interrupted by one putative intron of 56 bp. Southern blot analysis suggested that this was a singlecopy gene (Fig. 6). ${ }^{32} \mathrm{P}$-labeled PCR product was used to screen a lambda library of the pathogenic wheat isolate of $S$. nodorum, LAW95. Positive plaques were identified and purified, and DNA isolated from a single, strongly hybridizing clone. After restriction analysis and Southern hybridization with the labeled PCR product, the appropriate restriction fragments were subcloned into pUC18 and both strands se-

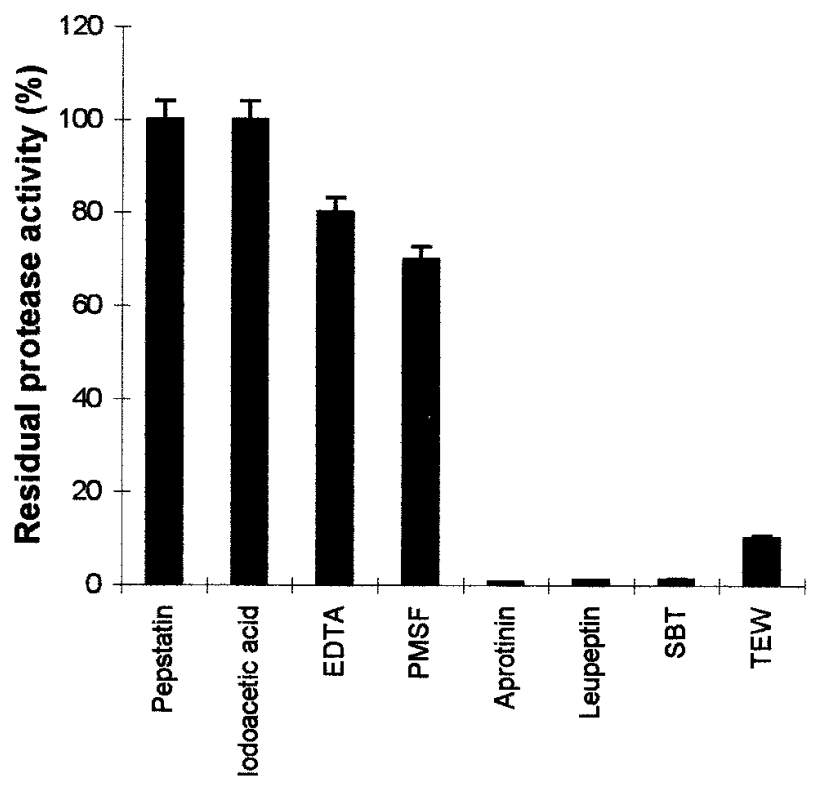

\section{Protease Inhibitors}

Fig. 4. Effect of protease inhibitors on the Stagonospora nodorum trypsin-like protease. Enzyme was pre-incubated with each inhibitor for 30 min before assay with Benz-Phe-Val-Arg-NA. Protease activities are expressed as a percentage of activity obtained in the control. Final concentrations of inhibitors: aprotinin, $1 \mu \mathrm{M}$; leupeptin, $1 \mathrm{mM}$; pepstatin, $10 \mu \mathrm{M}$; iodoacetic acid, $100 \mu \mathrm{M}$; phenylmethylsulfonyl fluoride (PMSF), $1 \mathrm{mM}$; ethylenediaminetetracetic acid (EDTA), $10 \mathrm{mM}$; soybean trypsin inhibitor (SBT), $100 \mu \mathrm{g} / \mathrm{ml}$; and turkey egg white inhibitor (TEW), $100 \mu \mathrm{g} \mathrm{ml}^{-1}$. Error bars represent the standard deviation about the mean of three replicates.

Table 2. Kinetic constants of substrates cleaved by SNP1

\begin{tabular}{lcc}
\hline Substrate & $\mathbf{K}_{\mathbf{m}}(\mathbf{m} \mathbf{M})$ & $\mathbf{V}_{\mathbf{m a x}}(\mathbf{m k a t} / \mathbf{m g})$ \\
\hline Benz-Phe-Val-Arg-NA & 0.25 & 7.3 \\
D-Val-Leu-Arg-NA & 0.3 & 7.5 \\
Benz-Pro-Phe-Arg-NA & 0.63 & 1.5 \\
D-Val-Phe-Lys-NA & 0.39 & 2.8 \\
\hline
\end{tabular}

quenced. The full-length sequence is shown in Figure 3. SNP1 encodes an open reading frame of 855 bp interrupted by a single, putative intron of $56 \mathrm{bp}$, indicated by lowercase letters. The intron was confirmed by sequencing the corresponding cDNA. The DNA sequence obtained from the genomic library of $S$. nodorum isolate LAW95 was identical to the sequence of the PCR product obtained from isolate BS171.

SNP1 is predicted to encode a protein of 265 amino acids $(29.4 \mathrm{kDa})$ that appears to be a preprotrypsin with a leader sequence of 36 amino acids, subject to post-translational modification. A putative signal-peptide cleavage site was identified after Ala at amino acid 20, based on the (-3-1) rule according to von Heijne (1986). This indicates a signal peptide of 20 amino acids, which would leave a possible propeptide of 16 amino acids between this signal peptide cleavage site and the consensus trypsin N-terminal sequence. Further proteolytic cleavage of this propeptide would result in a ma-

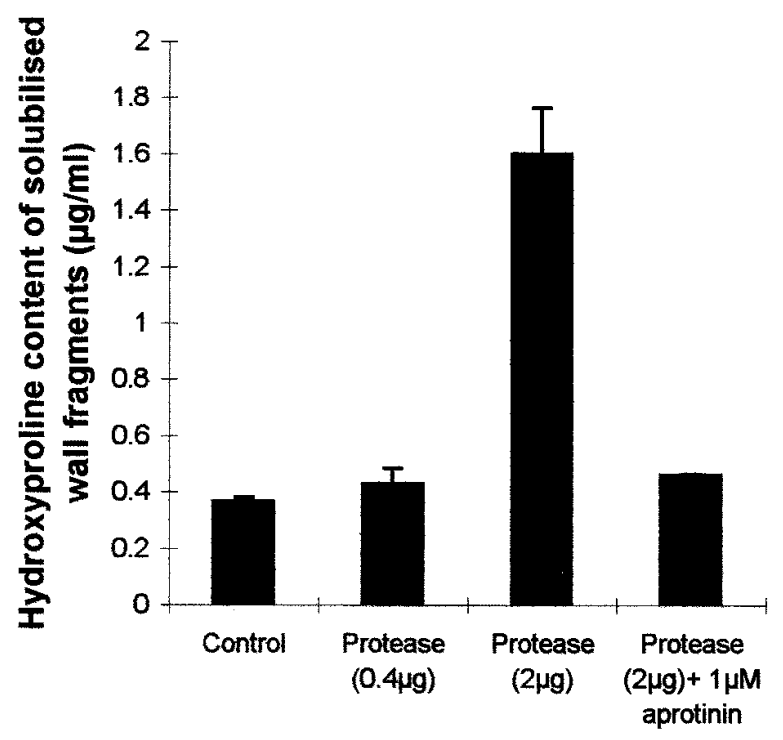

Treatment

Fig. 5. Release of hydroxyproline-containing proteins from wheat cell walls by SNP1. Pure SNP1 was incubated with $5 \mathrm{mg}$ of cell walls for 8 h. Soluble digestion products were hydrolyzed before assay for hydroxyproline content.

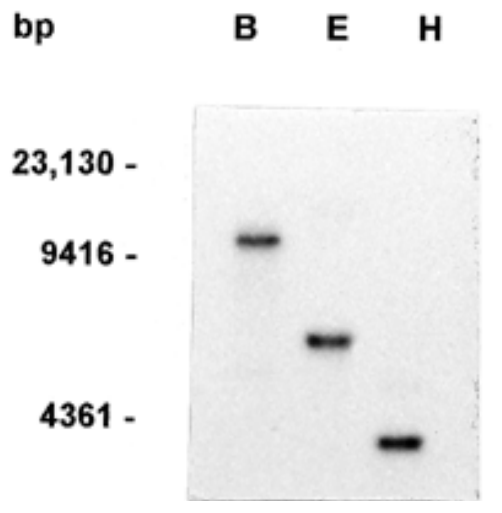

Fig. 6. Southern blot demonstrating the 610-bp polymerase chain reaction product from $S N P 1$ hybridizes to a single band. Genomic DNA (10 $\mu \mathrm{g}$ ) was cut with BamHI (B), EcoRI (E) and HindIII (H). 
ture protein of 229 amino acids $(25.4 \mathrm{kDa})$, which is in agreement with the size of SNP1 estimated by SDS-PAGE. The sequence alignment of SNP1 with other trypsins from filamentous fungi indicates that there is significant identity with $F$. oxysporum trypsin (64\%), C. carbonum ALP1 (56\%), and Metarhizium anisopliae TRY1 (55\%) (Fig. 7). SNP1 contains the catalytic triad common to all serine proteases, His-77, Asp-122, and Ser-218 (Neurath 1984).

Detection of protease in planta.

Protease activity was detected in both control and infected plant material throughout (2 to 14 days) infection (with BenzPhe-Val-Arg-NA as substrate). Levels in extracts from infected plants were approximately twice that observed in controls. When extracts from day 14 were eluted from a S-cation exchange column, the plant trypsin-like activity eluted at around fraction 19 and was present in both control and infected plants (Fig. 1B,C). Another peak at around fraction 13, which was absent or minimal in control plants, coeluted with the fungal protease (Fig. 1A). A similar peak was also apparent at days 2 and 7 (data not shown). Isoelectric focusing and subsequent gelatin overlay showed a single protease in these coeluting fractions with a $\mathrm{pI}$ of approximately 8.5, again consistent with the fungal trypsin with a pI of approximately 8.7 (data not shown). Activity in these fractions was also completely inhibited by the trypsin inhibitors aprotinin and leupeptin.

Expression of $S N P 1$ in planta.

Expression of SNP1 could be detected by Northern (RNA) blot analysis in infected but not in healthy leaves 7 days after inoculation with the aggressive isolate LN97, but was not detectable with the less aggressive isolate BS171 (Fig. 8A). However, SNP1 transcripts were detected from infected leaves 7 days after inoculation with either LN97 or BS171 by reverse transcription (RT)-PCR (Fig. 8B,C). As a positive control, expression of $S$. nodorum chitin synthase was also detected in infected leaves (Fig. 8D) whereas no amplification was detected in noninfected leaves or with wheat genomic DNA.

To investigate further $S N P 1$ expression in planta, isolate LAW95 was transformed with a vector carrying the SNP1 promoter fused to a green fluorescent protein (GFP) reporter

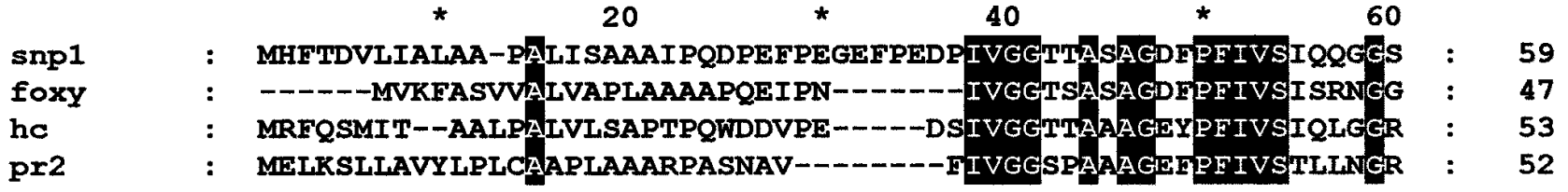

$\operatorname{snp} 1$

foxy

he

pr2

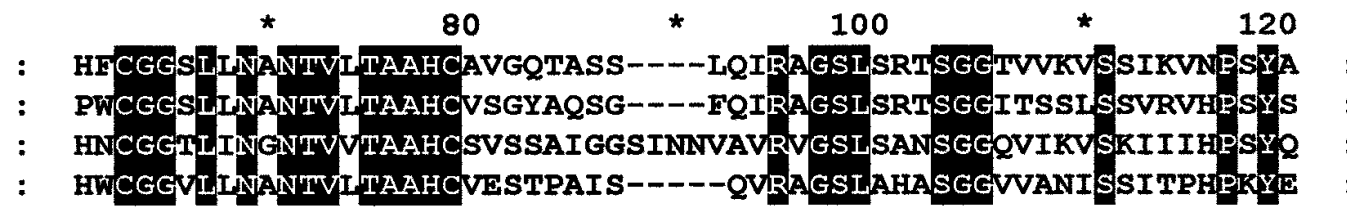

115

103

113

107

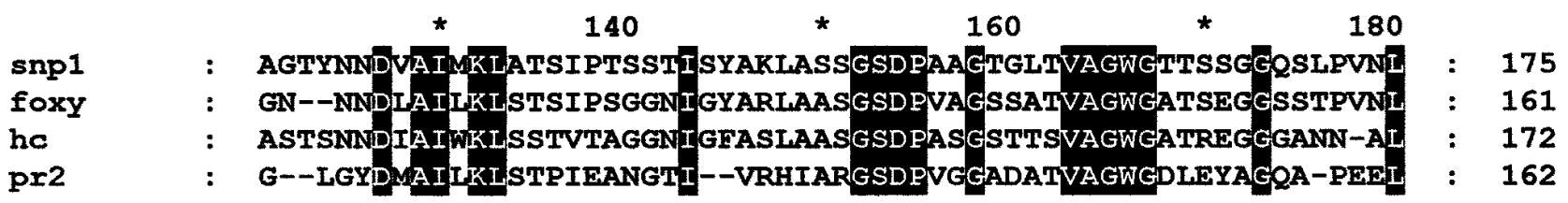

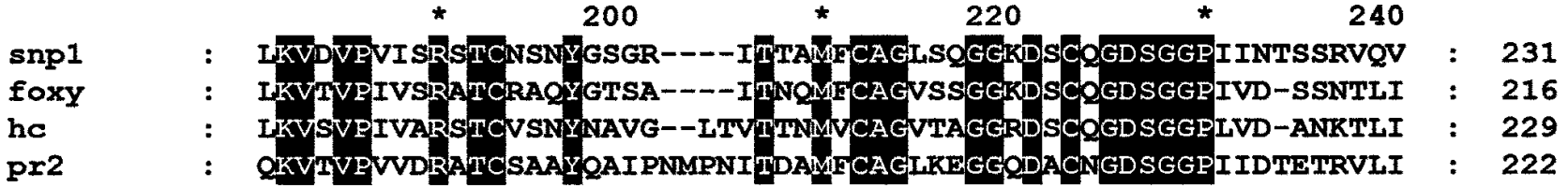

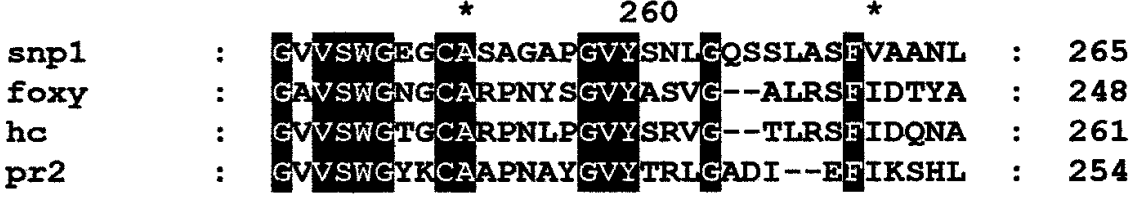

Fig. 7. Comparison of predicted amino acid sequences of SNP1 and three related trypsin-like proteases with PILEUP (Devereux et al. 1984). Sequence references: Fusarium oxysporum (foxy), SwissProt P35049, Rypniewski et al. (1993); Cochliobolus carbonum (hc), ALP1, Murphy and Walton (1996); Metarhizium anisopliae (pr2) tryl Smithson et al. (1995). Amino acid identity indicated by black background shading. 
gene (Spellig et al. 1996). As a positive control, the same isolate was also transformed with a vector carrying GFP fused to the constitutive $\beta$-tubulin gene promoter (Cooley and Caten 1993). To confirm inducibility of the SNP1 promoter, transformants were grown in complete medium, starved, and then transferred to basal salts plus $1 \%$ gelatin. pSNP1-GFP transformants expressed GFP when grown on gelatin, but not on complete medium. Transformants in which GFP was under the control of the $\beta$-tubulin promoter expressed GFP in both media (data not shown).

On wheat leaves inoculated with $5 \mu \mathrm{l}$ of spores transformed with the pSNP1-GFP construct, GFP fluorescence was apparent in hyphae after $24 \mathrm{~h}$ and was still detected 4 days post inoculation. Moreover, fluorescence was stronger in hyphae above or penetrating stomates (Fig. 9A,B). Fluorescence was uniform in hyphae of the pTUBA-GFP transformant expressing GFP constitutively (Fig. 9C).

\section{DISCUSSION}

SNP1 has been isolated and characterized from $S$. nodorum as a typical fungal trypsin-like protease. We have shown that

\section{Myc wheat leaves 171 Con LN 171}
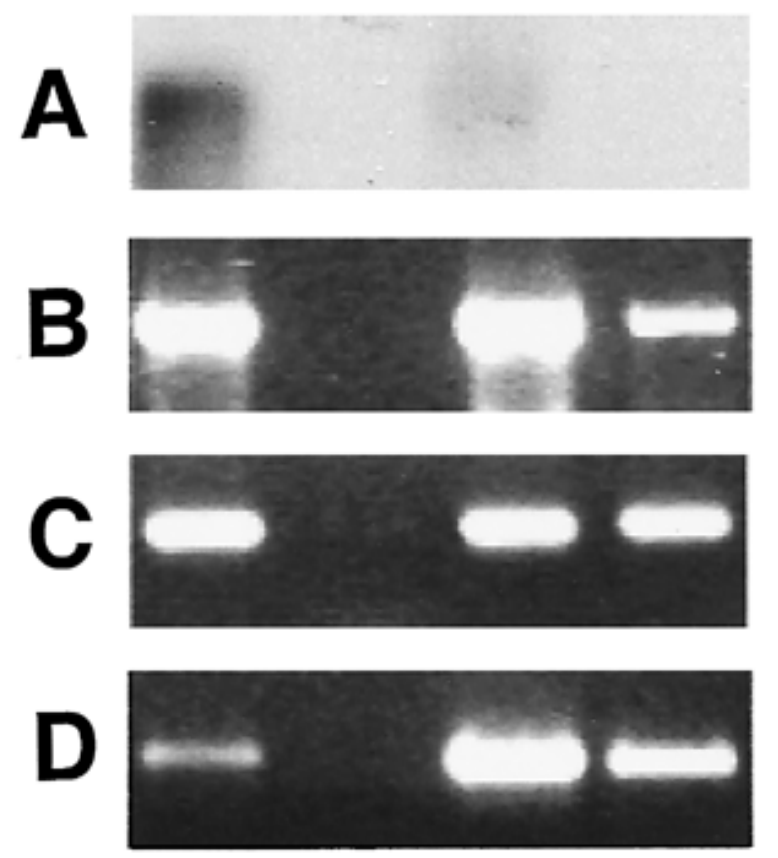

Fig. 8. Detection of SNP1 RNAs from in vitro cultures and infected wheat leaves. Myc: 2-day-old Stagonospora nodorum isolate BS171 cultured in Czapek-Dox V8 liquid medium was starved for $8 \mathrm{~h}$ in basal salts prior to transfer to basal salts containing $1 \%(\mathrm{wt} / \mathrm{vol})$ wheat cell walls for $16 \mathrm{~h}$ of growth; wheat leaves with no spores as a negative control (Con), or infected with $10^{6}$ spores per ml of S. nodorum strain LN (LN) or BS171 strain (171). Leaves were harvested 7 days post inoculation. A, Northern (RNA) blot hybridized with SNP1. B-D, Agarose gel of reverse transcription-polymerase chain reaction products amplified with (B) SNP1 primers F1b-R11, (C) SNP1 primers F12-R15, or (D) chitin synthase primers CHSF-CHSR.
SNP1 is able to degrade native protein(s) in wheat cell walls, and that the mRNA is expressed during infection as shown by Northern blot analysis, RT-PCR, or GFP expression under control of the SNP1 promoter. This coincided with the production of a trypsin by $S$. nodorum in planta.

The substrate specificity of this enzyme is typically trypsinlike, specifically cleaving the peptide bond on the carboxyl side of lysine or arginine residues (Kraut 1977; Steitz and Shulman 1982). The exact Arg or Lys preference for this enzyme requires further study. Bovine trypsin shows a preference for lysine over arginine residues, while in $F$. oxysporum this specificity is reversed (Rypniewski et al. 1993). Alterations in the p2 and p3 subsites also alter activity; there was an $80 \%$ reduction in $\mathrm{V}_{\max }$ between the Benz-Phe-Val-Arg-NA substrate and Benz-Pro-Phe-Arg-NA. A trypsin-like protease of the entomopathogenic fungus $M$. anisopliae showed a $92 \%$ reduction in $\mathrm{V}_{\max }$ against the same substrates (St. Leger et al. 1996). When Phe is at the p2, Lys was preferentially cleaved over Arg by SNP1. The ability of SNP1 to cleave Lys residues may be of relevance in view of their abundance in the plant cell wall extensins (Showalter 1993).

Although frequently implicated in pathogenicity, the exact role of proteases in infection by plant pathogens has yet to be determined. If they are cell wall-degrading enzymes, then they would be expected to degrade structural wall proteins, which mainly consist of HRGPs. It has been suggested previously that protease(s) produced by $S$. nodorum may play a role in degradation of protein in the aleurone layer of seeds when causing glume blotch (Sieber 1989). SNP1 is highly active against the substrate azocoll and is produced in large amounts when grown on hydroxyproline-rich collagen in liquid culture. Also, pure SNP1 with no other associated enzyme activities released hydroxyproline, presumably from structural proteins in the wheat cell wall. There are few reported cases of proteases from plant pathogens able to degrade host cell wall proteins other than metalloprotease(s) from Erwinia carotovora subsp. carotovora against HRGPs from potato and tomato (Heilbronn et al. 1995; Willis et al. 1987) and a metalloprotease from $X$. campestris that degraded a PRP from Brassica campestris but had no activity on model protein substrates (Dow et al. 1998). Thus, cell wall degradation is a new function that might be assigned to proteases. However, Alp1a and Alp1b, trypsin-like proteases of $C$. carbonum, although produced on collagen, had no activity against maize extensins (Murphy and Walton 1996). Trypsins can cleave extensins of dicots and monocots but usually only after removal of the extensive glycosyl groups; thus, the one to four arabinosyl residues found on most hydroxyproline residues in dicots must first be removed with anhydrous hydrogen fluoride (Kieliszewski et al. 1989; Smith et al. 1986). Typically in monocots only less than half the hydroxyproline residues are glycosylated (Lamport and Miller 1971; Showalter 1993). Linkages in cereal cell walls vulnerable to SNP1 will presumably involve arginyl and lysyl bonds. Extensins and PRPs such as maize HRGP, which consists of $13 \mathrm{~mol} \%$ Lys, are lysine rich. There are repeats containing Arg in GRPs and in maize PRP (Showalter 1993). Lys-Pro links are usually trypsin resistant but there is one that is trypsin vulnerable in a palindromic Lys-Pro-Lys repeat of a maize THRGP (Kieliszewski et al. 1989). Therefore, it will be our aim to determine the putative protein target(s) of SNP1 in the wheat cell wall. 
Unfortunately, there is little information on wheat cell wall proteins, although wheat, barley, and rice of the Festuciodeae subfamily share nucleotide sequences related to that of maize HRGP (Raz et al. 1991). Thus, there are potentially vulnerable peptide bonds in wall proteins from cereals, which becomes more relevant in light of their low glycosylation, compared with HRGPs of dicots. Pathogens of dicots could require arabinosidases to act synergistically with proteases to achieve extensin degradation but proteases may be able to degrade monocot extensins directly, as suggested by this work. Nevertheless, high levels of arabinosidases of $S$. nodorum are also raipdly produced in vitro and are present in vivo (data not shown). It is also interesting to note that a high pI xylanase initially co-purified with SNP1, and this is one of the most abundant enzymes produced by $S$. nodorum when grown on wheat cell walls. The importance of xylan in the wheat cell wall (>40\% wt/wt) (Carpita and Gibeaut 1993) and the demonstration that this pure xylanase can also degrade the wheat cell wall (data not shown) suggest that these two enzymes, with similar charge and regulation by host cell walls, may have a very destructive effect on the wall when secreted together in vivo.

Detection of enhanced putative pathogen depolymerases in infected host plants is complicated by the presence of related plant enzymes such as proteases, which may also be induced during plant-pathogen interactions (Lusso and Kuc 1995; D'Silva et al. 1998). However, primers used for the RT-PCR were specific to SNP1. Moreover, GFP transformants showed that the SNP1 promoter is activated in growing hyphae by 24 $\mathrm{h}$ after inoculation with $S$. nodorum spores. Therefore, the increased trypsin activity detected in infected plants is likely to be of fungal origin since it shares properties with SNP1 (inhibitor sensitivity, $M_{\mathrm{r}}$, pI, elution from S-column). Similarly, Movahedi and Heale (1990a) showed the coelution of an aspartic protease from infected carrot tissue with an aspartic protease from Botrytis cinerea. Also, a subtilisin-like protease was produced by Magnaporthe poae in infected roots of Kentucky bluegrass (Sreedhar et al. 1999). Nevertheless, the importance of proteases as virulence factors remains unclear despite reports on protease-deficient mutants of $X$. campestris and P. brassicae (Dow et al. 1990; Ball et al. 1991) that are less pathogenic than the wild-type strain. In many cases, gene mutation, disruption, or deletion of proteases did not affect pathogenicity, as reported for Erwinia chrysanthemi, C. heterostrophus, C. cucumerinum, and C. carbonum (Dahler et al. 1990; Walton 1994; Robertson 1984; Murphy and Walton 1996). In some of these cases, the lack of phenotype modification might be due to residual protease activity because of the presence of other isoforms, or result from the expression of proteases from other families. Moreover, virulence may be conferred by a set of cell wall-degrading enzymes acting in concert, such as xylanases, arabinosidases, and SNP1 of S. nodorum, rather than each component functioning independently.

SNP1 is a putative virulence factor in view of its activity on cell walls and its rapid induction in planta. Therefore, further studies are underway to determine the importance of SNP1 in disease by several approaches, which include degradation of wheat wall proteins (in situ and extracted) and targeted gene deletion. The unusual situation of a microbial depolymerase consisting of a single-copy gene and no other apparent isoforms should facilitate the latter strategy.

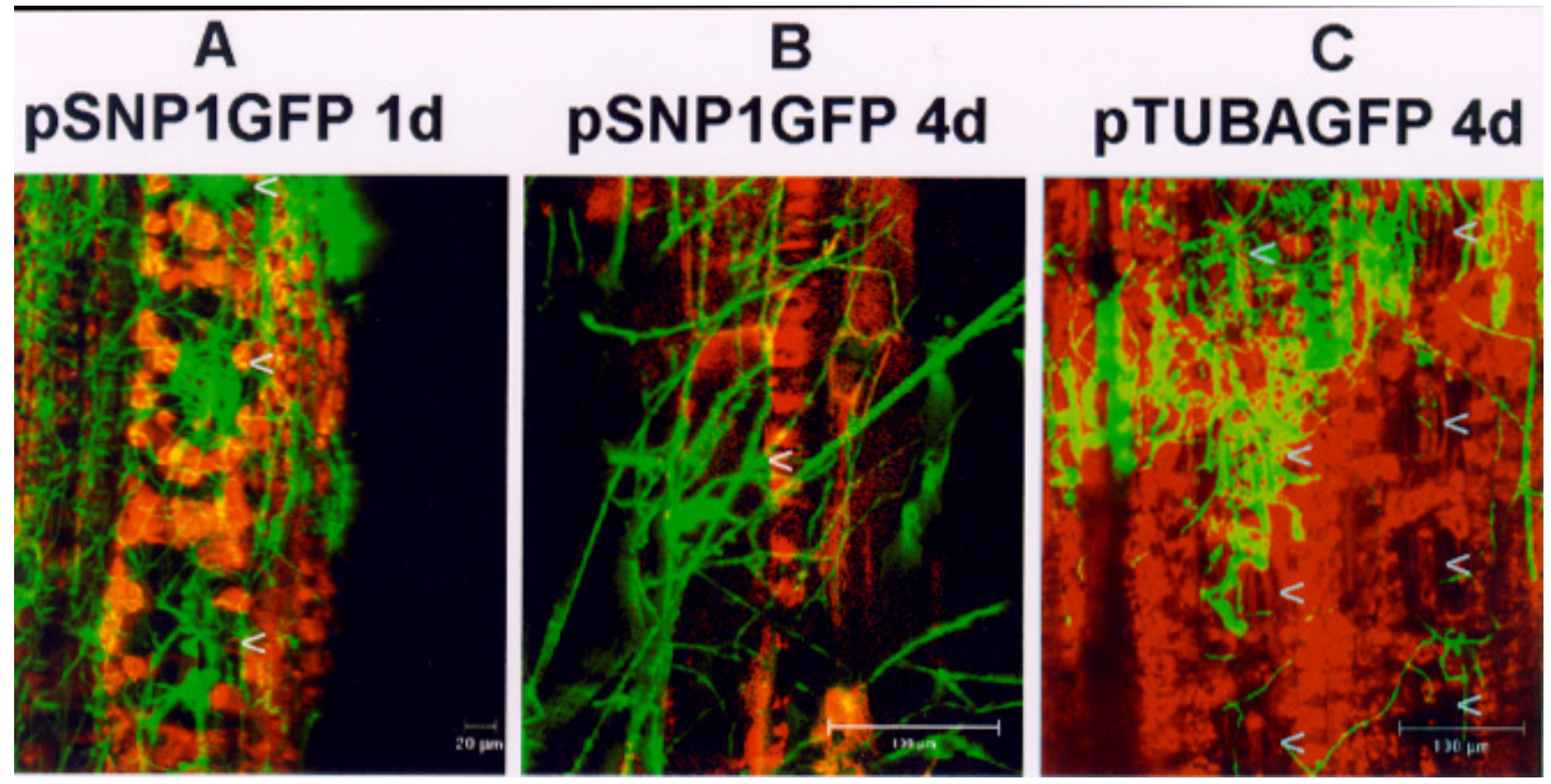

Fig. 9. Confocal microscopy of wheat leaves infected with Stagonospora nodorum transformed with a plasmid coding for green fluorescent protein (GFP) fused to (A,B) the SNP1 promoter (pSNP1GFP) or (C) with a plasmid coding for GFP fused to the constitutive promoter of $S$. nodorum tubulin (pTUBAGFP). Observations were made 1 or 4 days post inoculation. Excitation wavelength, $488 \mathrm{~nm}$; detection, 510-520 nm (green channel) and 600$650 \mathrm{~nm}$ (red channel). Green fluorescence corresponds to GFP expression; red fluorescence comes from underlying chlorophyll. A, Three aligned stomates with more intense GFP green fluorescence in mycelium above stomates. B, A single stoma with associated hyphae showing stronger fluorescence than elsewhere on the surface. C, Two rows of four stomates but relatively uniform fluorescence in overlying hyphae. Position of stomates shown by arrows. Scale bars: $\mathbf{A}, 20 \mu \mathrm{m} ; \mathbf{B}, 100 \mu \mathrm{m} ; \mathbf{C}, 100 \mu \mathrm{m}$. These images are representative of many observations from five replicate inoculations. 


\section{MATERIALS AND METHODS}

\section{Fungal isolate.}

Septoria nodorum isolates BS171 (originally isolated from barley; Osbourn et al. 1986) and LN97 were obtained from AgrEvo (Saffron Walden, UK); a wheat isolate, LAW95, was from IACR, Long Ashton, Bristol (Hall et al. 1999). The fungus was grown on Czapek-Dox V8 agar (Newton and Caten 1988) under continuous UV at $20^{\circ} \mathrm{C}$ for 5 to 7 days to achieve sporulation.

\section{Growth of $S$. nodorum in liquid culture.}

For the production of protease the fungus was grown in shake culture. First, a fungal biomass was established in a complete liquid medium containing, per liter, $45.4 \mathrm{~g}$ of Czapek-Dox medium, $200 \mathrm{ml}$ of filtered V8 juice, and $100 \mathrm{ml}$ of Complete Supplement (Newton and Caten 1988). Spores (2 $\times 10^{7}$ ) were inoculated into $250-\mathrm{ml}$ Erlenmeyer flasks containing $100 \mathrm{ml}$ of medium. The cultures were grown for $48 \mathrm{~h}$ at $24^{\circ} \mathrm{C}, 120 \mathrm{rpm}$ on a rotary shaker (Sanyo Gallenkamp, Loughborough, UK), then were filtered through muslin, washed with $50 \mathrm{mM}$ MES [2-( $N$-morpholino)ethanesulfonic acid) $\mathrm{pH} 6.0$ and transferred for a 12 -h period of starvation to a basal salts liquid medium that contained, per liter, $1 \mathrm{~g}$ of $\mathrm{KH}_{2} \mathrm{PO}_{4}, 0.5 \mathrm{~g}$ of $\mathrm{MgSO}_{4} \cdot 7 \mathrm{H}_{2} \mathrm{O}, 9.76 \mathrm{~g}$ of MES (50 mM), and $10 \mathrm{ml}$ of trace elements solution (containing, per liter, $1 \mathrm{~g}$ $\mathrm{KH}_{2} \mathrm{PO}_{4}, 0.5 \mathrm{~g}$ of $\mathrm{MgSO}_{4} \cdot 7 \mathrm{H}_{2} \mathrm{O}, 20 \mathrm{mg}$ of $\mathrm{FeSO}_{4} \cdot 7 \mathrm{H}_{2} \mathrm{O}, 100$ $\mathrm{mg}$ of $\mathrm{ZnSO}_{4}, 2 \mathrm{mg}$ of $\mathrm{NaMoO}_{4} \cdot 2 \mathrm{H}_{2} \mathrm{O}, 2 \mathrm{mg}$ of $\mathrm{CuSO}_{4} \cdot 5 \mathrm{H}_{2} \mathrm{O}$, $2 \mathrm{mg}$ of $\mathrm{MnCl}_{2} \cdot 4 \mathrm{H}_{2} \mathrm{O}$ ). $\mathrm{pH}$ was adjusted to 6.0 with $1 \mathrm{M}$ $\mathrm{NaOH}$ prior to autoclaving. After $12 \mathrm{~h}$, cultures were strained through muslin and washed with $50 \mathrm{mM}$ MES before transfer to inducing medium consisting of basal salts medium (as above) plus $1 \%$ (wt/vol) wheat cell walls.

\section{Production of wheat cell walls.}

Wheat cell walls were prepared from 14-day-old plants (cultivar Hornet) grown in trays at approximately $25^{\circ} \mathrm{C}$ under a 12-h photoperiod regime. Plants were chopped, then ground in liquid nitrogen. Ground plant material was then soaked in 2.5 volumes of ice-cold $0.1 \mathrm{M}$ phosphate buffer, $\mathrm{pH} 6$ before comminution in a Waring blender on high speed for 2 to 3 min. The resulting suspension was filtered through two layers of muslin and the insoluble plant material resuspended in 2 volumes of cold phosphate buffer and allowed to stand for 5 min. This was repeated to a total of four washes in buffer and finally one in cold, distilled water. Solvent extractions were performed with four washes of 1 volume chloroform:methanol $(1: 1, \mathrm{vol} / \mathrm{vol})$ and three washes of 2 volumes of acetone. All extractions were made at $4^{\circ} \mathrm{C}$. Cell wall material was left to dry overnight at room temperature then kept desiccated until required.

\section{Enzyme assays.}

Enzyme substrates were from Sigma (Poole, UK).

Trypsin-like protease activity was measured spectrophotometrically against the nitroanilide substrate, Benzoyl-PheVal-Arg-Nitroanilide. Reaction mixtures contained $50 \mu \mathrm{l}$ of enzyme solution, $100 \mu \mathrm{l}$ of $50 \mathrm{mM}$ Tris- $\mathrm{HCl} \mathrm{pH} 8$, and $50 \mu \mathrm{l}$ of $2 \mathrm{mM}$ substrate made up in dimethyl sulfoxide (DMSO). Nitroanilide release was monitored at $405 \mathrm{~nm}$ over $15 \mathrm{~min}$. General protease activity was measured against azocasein.
Reactions consisted of $100 \mu \mathrm{l}$ of $3 \%$ azocasein in $10 \mathrm{mM}$ Tris$\mathrm{HCl} \mathrm{pH} \mathrm{8.0,} 350 \mu \mathrm{l}$ of $10 \mathrm{mM}$ Tris-HCL, and $50 \mu \mathrm{l}$ of enzyme sample or blank. Incubations at $37^{\circ} \mathrm{C}$ for $3 \mathrm{~h}$ were then stopped with $550 \mu \mathrm{l}$ of $20 \%$ trichloroacetic acid (TCA), mixed, and clarified by centrifugation. Release of the red azo dye was monitored at $A_{340}$.

\section{Substrate specificity.}

Activity against other nitroanilide substrates was assayed under the same conditions with the substrates Suc-(Ala) $)_{2}$-ProPhe-NA, CBZ-Gly-Gly-Leu-NA, Benz-Phe-Val-Arg-NA, Benz-Pro-Phe-Arg-NA, D-Val-Leu-Arg-NA, Benz-DL-ArgNA, and D-Val-Phe-Lys-NA.

\section{Protein assays.}

Protein determinations were carried out by the dye binding method (Bradford 1976) in which Bio-Rad (Hemel Hempstead, UK) reagents were used with bovine serum albumin as standard.

\section{Protease purification.}

After $48 \mathrm{~h}$ of growth in inducing medium with $1 \%$ wheat cell walls, $500 \mathrm{ml}$ of culture filtrate was harvested by filtration through two layers of muslin. Proteins were concentrated by precipitation with ammonium sulfate ( $80 \%$ saturation). The precipitate was resuspended in $50 \mathrm{ml}$ of $25 \mathrm{mM}$ MES pH 6.0 and dialyzed against several changes of MES buffer for $24 \mathrm{~h}$. This retentate was then centrifuged at $14,000 \times g$ for $15 \mathrm{~min}$ and the supernatant filtered through a $0.2 \mu \mathrm{m}$ nitrocellulose filter. Ten milliliters of this concentrated extract was applied to a 5-ml cation exchange column (High trap SP Sepharose; Amersham-Pharmacia Biotech, St. Albans, UK) run on a Pharmacia FPLC system and eluted over a $0-175 \mathrm{mM} \mathrm{NaCl}$ gradient in $25 \mathrm{mM}$ MES pH 6.0 at $1 \mathrm{ml} / \mathrm{min}$. Fractions with trypsin activity (versus Benz-Phe-Val-Arg-NA) were then buffer exchanged into $50 \mathrm{mM} N$-2-hydroxyethylpiperazine- $N^{\prime}$ 2-ethanesulfonic acid (HEPES)-MES-Na Ac at $\mathrm{pH} 4.5$ before injection onto a 0.8-ml-high resolution cation exchange column (HS20 Poros; Boehringer-Mannheim-Roche, Lewes, UK) run on a Biocad Sprint Perfusion Chromatography System (Perseptive Biosystems, Framington, MA) equilibrated in 50 $\mathrm{mM}$ HEPES-MES-NaAc at $\mathrm{pH} 4.5$, and eluted in this same buffer over a 0-200 $\mathrm{mM} \mathrm{NaCl}$ gradient. The molecular mass and purification of the protease were monitored with denaturing SDS-PAGE with 12\% acrylamide (Laemmli 1970).

\section{Isoelectric focusing.}

Isoelectric focusing was performed with precast polyacrylamide gels and $\mathrm{pI}$ markers in the $\mathrm{pH}$ range 3 to 9.5 (Amersham-Pharmacia Biotech). Protease activity was detected in replica gels by overlaying gels with unprocessed, gelatin-coated X-ray film incubated previously for $10 \mathrm{~min}$ in water (Abraham and Breuil 1996). Protease activity was observed as a blue clearing zone on the film due to degradation of the gelatin layer after approximately $30 \mathrm{~min}$ at room temperature.

\section{Temperature and pH optima.}

Pure protease activity was assayed over a range of $\mathrm{pH}$ values with five overlapping buffers to cover $\mathrm{pH} 5.5$ to 11 . All were used at $50 \mathrm{mM}$ : MES pH 5.5 to $6.5 ; 3$ - $(N$-morpholino $)$ 
propanesulfonic acid (MOPS) $\mathrm{pH} 6.5$ to 7.5 ; Tris- $\mathrm{HCl} \mathrm{pH} 7.5$ to 8.5 ; Glycine- $\mathrm{NaOH}$ pH 8.5 to 9.0 ; 3-(cyclohexylamino)-1propanesulfonic acid (CAPS) pH 9.5 to 11. Temperature optimum was estimated by assaying at a range of temperatures with a 15 -min incubation time.

\section{Temperature and pH stability.}

Pure protease was incubated for $1 \mathrm{~h}$ at $4^{\circ} \mathrm{C}$ over the $\mathrm{pH}$ range 5.5 to 11 with five overlapping buffers before assay. Temperature stability was determined by assay following a 1$\mathrm{h}$ incubation over the temperature range 4 to $60^{\circ} \mathrm{C}$.

\section{Metal ion requirement.}

Pure protease was extensively dialyzed against several changes of $25 \mathrm{mM}$ MES pH 6 and then incubated with a range of metal ions for $30 \mathrm{~min}$ before assay. Metal ions were used in the concentration range 1.25 to $10 \mathrm{mM}$.

\section{Inhibitor studies.}

Pure protease was incubated with the following inhibitors for $30 \mathrm{~min}$ before assay against Ben-Phe-Val-Arg-NA (concentrations are final concentrations in reaction mixtures): aprotinin $(1 \mu \mathrm{M})$, leupeptin $(1 \mathrm{mM})$, PMSF $(1 \mathrm{mM})$, EDTA $(10 \mathrm{mM})$, iodoacetate $(100 \mu \mathrm{M})$, pepstatin $(1 \mu \mathrm{M})$, soybean trypsin inhibitor $\left(100 \mu \mathrm{g} \mathrm{ml}^{-1}\right)$, turkey egg white inhibitor (100 $\mu \mathrm{g} \mathrm{ml} \mathrm{m}^{-1}$.

\section{Effect of SNP1 on wheat cell walls.}

Five milligrams of wheat cell wall was washed for $1 \mathrm{~h}$ with agitation in $50 \mathrm{mM}$ Tris- $\mathrm{HCl}, \mathrm{pH}$. Washed walls were then centrifuged at $11,000 \times g$ for $15 \mathrm{~min}$ and the buffer removed. This was replaced with $950 \mu \mathrm{l}$ of fresh buffer and $50 \mu \mathrm{l}$ of test or control sample prepared in similar buffer. Samples were incubated with agitation at $25^{\circ} \mathrm{C}$ for $8 \mathrm{~h}$ before centrifugation at $11,000 \times g$ for $15 \mathrm{~min}$. Supernatants containing degradation products were removed and transferred to Pyrex tubes with Teflon-lined lids. Proteins in the sample were then hydrolyzed in $6 \mathrm{M} \mathrm{HCl}$ (final concentration) for $20 \mathrm{~h}$ at $110^{\circ} \mathrm{C}$ to release free hydroxyproline. Samples were then lyophilized before assay for hydroxyproline by the methods of Kivirikko and Liesmaa (1959). Solutions used for assay were as follows: A = $180 \mu \mathrm{l}$ of bromine dissolved in $50 \mathrm{ml}$ of ice-cold $1.25 \mathrm{M}$ $\mathrm{NaOH} ; \mathrm{B}=16 \% \mathrm{Na}_{2} \mathrm{SO}_{3} ; \mathrm{C}=5 \%$ p-dimethylaminobenzaldehyde in propan-1-ol; $\mathrm{D}=6 \mathrm{M} \mathrm{HCl}$. Samples were resuspended in $300 \mu \mathrm{l}$ of $\mathrm{dH}_{2} \mathrm{O}$ and cooled on ice. Three hundred microliters of ice-cold A was then added, shaken vigorously, and incubated on ice for $10 \mathrm{~min}$. Fifteen microliters of B was then added, followed by $300 \mu \mathrm{l}$ of $\mathrm{C}$, and finally $150 \mu \mathrm{l}$ of D. Samples were shaken between each addition. Samples were then incubated at $95^{\circ} \mathrm{C}$ for $2.5 \mathrm{~min}$ followed by $10 \mathrm{~min}$ at $20^{\circ} \mathrm{C}$. Absorbance was read at $560 \mathrm{~nm}$ and compared with a standard curve of hydroxyproline over the range 0.1 to $2.0 \mu \mathrm{g}$. Total hydroxyproline levels in cell walls were calculated following hydrolysis of walls with $6 \mathrm{M} \mathrm{HCl}$ as above.

\section{Inoculation of plant material.}

For extractions of protease, 7-day-old wheat plants of cv. Hornet, which is moderately susceptible to $S$. nodorum, were sprayed to just before run-off with a suspension of $5 \times 10^{5}$ spores $\mathrm{ml}^{-1}$ prepared in $0.02 \%$ Tween 20 . Plants were covered in polythene for $48 \mathrm{~h}$ to maintain a high humidity and grown at $20^{\circ} \mathrm{C}$ with a 12 -h light and 12 -h dark cycle. Control plants were sprayed with $0.02 \%$ Tween 20 alone. Infected material was harvested at 2, 7, and 14 days after inoculation, corresponding to water-soaking, chlorosis and some necrosis, and necrotic tissue, respectively.

For extraction of RNA, inoculation of excised leaves gave more reproducible and severe symptoms. First leaves of 15day-old wheat cv. Brigadier were excised and rubbed with a wet paper pad. The apical $10 \mathrm{~cm}$ was laid on water agar plates containing $150 \mu \mathrm{g} \mathrm{ml}^{-1}$ benzimidazole. The adaxial surface was inoculated by brush with $10^{6}$ spores $\mathrm{ml}^{-1}$ of $S$. nodorum in $0.02 \%$ Tween 20 . One-half to $1 \mathrm{~g}$ of control or infected leaves was harvested after 7 days for extraction with Trizol reagent (GibcoBRL Life Technologies, Paisley, UK) (see below).

\section{Extraction of protease from wheat plants.}

Forty grams of plant material was comminuted in liquid nitrogen and the powder suspended in $200 \mathrm{ml}$ of cold extraction buffer, consisting of $50 \mathrm{mM}$ sodium phosphate buffer $\mathrm{pH} 6$ (5 $\mathrm{ml} \mathrm{g}^{-1}$ tissue) containing $5 \mathrm{mM}$ dithiothreitol (DTT; to prevent oxidation), $0.2 \mathrm{M} \mathrm{NaCl}$ (to desorb proteins from cell walls), and $5 \%$ (wt/vol) polyvinyl pyrrolidone (to adsorb phenols). After being shaken on ice for $15 \mathrm{~min}$, extracts were centrifuged at $4,000 \times g$ for $15 \mathrm{~min}$, then the supernatant was respun at $23,000 \times g$ for $15 \mathrm{~min}$. Proteins in the supernatant were precipitated with ammonium sulfate to $100 \%$ saturation and the precipitate resuspended in $25 \mathrm{mM}$ MES pH 6 before extensive dialysis against $25 \mathrm{mM}$ MES pH6 at $4^{\circ} \mathrm{C}$. Extracts were then concentrated to approximately $20 \mathrm{ml}$ in a saturated solution of polyethylene glycol (PEG) $20,000 M_{\mathrm{r}}$.

\section{Detection of fungal protease in infected plant tissue.}

Ten milliliters of concentrated fungal culture filtrates prepared as previously described (see above) was applied to a $\mathrm{S}$ Sepharose (fast flow; Sigma) cation exchange column $(10 \mathrm{ml})$ equilibrated with $25 \mathrm{mM}$ MES $\mathrm{pH}$ 6.0. The protease was eluted over a $0-250 \mathrm{mM} \mathrm{NaCl}$ gradient and fractions assayed for fungal trypsin activity. Ten milliliters of each dialyzed plant extract was loaded and eluted from this column under the same conditions. These fractions were subjected to gel isoelectric focusing and subsequent gelatin overlay to determine the $\mathrm{pI}$ of the protease activity.

\section{Effects of SNP1 on viability of tritordeum cells.}

The effect of SNP1 on the viability of tritordeum cells was studied with cells at $0.05 \mathrm{~g} / \mathrm{ml}$ in assay medium containing 0.5 $\mathrm{mM}$ MES, $0.5 \mathrm{mM} \mathrm{CaCl}_{2}, 0.5 \mathrm{mM} \mathrm{K}_{2} \mathrm{SO}_{4}$, and $175 \mathrm{mM}$ mannitol and adjusted to pH 5.7 (Baker and Mock 1994). Log concentrations of pure SNP1 from 0.04 to $40 \mu \mathrm{g}$, corresponding to 35 nkats to $20 \mu \mathrm{kats}$ of activity/ml of reaction, respectively, were used in reactions performed in triplicate. SNP1 was incubated with suspension cells shaken at $120 \mathrm{rpm}$ (Sanyo Gallenkamp, Loughborough, UK), $25^{\circ} \mathrm{C}$, then $100 \mu \mathrm{l}$ of suspension was removed at 2, 6, 24, and $48 \mathrm{~h}$, and added to 1:1 ( $\mathrm{vol} / \mathrm{vol})$ fluorescein diacetate $\left(1 \mathrm{mg} \mathrm{ml}^{-1}\right)$; viability was determined by fluorescence microscopy.

\section{Nucleic acid manipulations and sequencing.}

Genomic DNA was prepared as described by Raeder and Broda (1985) from harvested mycelia grown for $48 \mathrm{~h}$ on complete medium (described above). Sequencing was performed 
with an ABI-377 automated fluorescence sequencer with the Perkin-Elmer dye-terminator kit (PE Applied Biosystem, Warrington, UK). Sequence was compiled and analyzed by GCG programs (Devereux et al. 1984).

\section{PCR isolation of SNP1.}

PCR amplification of a 610-bp region of SNP1 was performed in $25-\mu 1$ reaction with $0.2 \mathrm{mM}$ concentrations of each dNTP, $1.5 \mathrm{mM} \mathrm{MgCl}_{2}, 1 \mathrm{U} \mathrm{Taq}$ polymerase, 50 pmol primer, and $50 \mathrm{ng}$ of genomic DNA. Amplification cycle was as follows: 1 min $94^{\circ} \mathrm{C} ; 35$ cycles $\left(1 \min 94^{\circ} \mathrm{C}, 1 \mathrm{~min} 55^{\circ} \mathrm{C}\right.$, and 1 $\left.\min 72^{\circ} \mathrm{C}\right) ; 5 \min 72^{\circ} \mathrm{C}$. PCR primers used were $\mathrm{AT}(\mathrm{H})$ $\mathrm{GT}(\mathrm{N}) \mathrm{GG}(\mathrm{N}) \mathrm{GG}(\mathrm{N}) \mathrm{AC}(\mathrm{N}) \mathrm{AC}(\mathrm{N}) \mathrm{GC}$, corresponding to the $\mathrm{N}$-terminal amino acid sequence IVGGTTA, and GG(N) $\mathrm{CC}(\mathrm{N}) \mathrm{CC}(\mathrm{N}) \mathrm{SWRTC}(\mathrm{N}) \mathrm{CC}(\mathrm{Y}) \mathrm{TGRCA}$, corresponding to the active site amino acid sequence CQGDSGGP. The 610-bp product was eluted from the gel and sequenced directly with the two primers. Ten micrograms of genomic DNA was digested with BamHI, EcoRI, and HindIII restriction endonucleases and after Southern transfer probed with the 610-bp SNP1 PCR fragment. Hybridization conditions were $0.265 \mathrm{M}$ $\mathrm{Na}_{2} \mathrm{HPO}_{4} \cdot 2 \mathrm{H}_{2} \mathrm{O}$ pH 7.2 with $7 \%$ SDS and $1 \%$ skimmed milk powder at $65^{\circ} \mathrm{C}$; the most stringent wash was 15 min $0.5 \times$ $\mathrm{SSC}$ ( $1 \times \mathrm{SSC}$ is $0.15 \mathrm{M} \mathrm{NaCl}$ plus $0.015 \mathrm{M}$ sodium citrate) / $0.1 \%$ SDS at $65^{\circ} \mathrm{C}$.

\section{Isolation of full-length $S N P 1$.}

Duplicate Hybond-N filters (Amersham-Pharmacia Biotech) representing 10,000 plaques from a genomic library of $S$. nodorum isolate LAW 95, constructed in lambda GEM11 (Promega, Southampton, UK), were screened with the ${ }^{32} \mathrm{P}$ labeled, 610-bp SNP1 PCR fragment. Hybridization conditions were the same as above and final washes were $15 \mathrm{~min}$ each of $2 \times$ SSC / 0.1\% SDS and 0.5× SSC / 0.1\% SDS. Positive clones were identified and re-screened twice before lambda DNA was purified from the most strongly hybridizing clones. Following DNA isolation, restriction, and Southern blotting, positively hybridizing bands were subcloned into pUC18 and sequenced. Several different SalI fragments were used as templates for sequencing with alternative restriction fragment templates used to confirm sequence across $\mathrm{SalI}$ sites.

\section{Northern blotting.}

Two-day-old cultures of $S$. nodorum grown in Czapek-Dox V8 agar medium were starved for $8 \mathrm{~h}$ in basal salts. One gram fresh weight of starved mycelium was transferred to $15 \mathrm{ml}$ of basal salts containing $1 \%$ wheat cell walls (wt/vol) and incubated for a further $16 \mathrm{~h}$. Extraction of RNA and blotting were as described by Vallélian-Bindschedler et al. (1998). Probes were labeled with an oligolabeling kit (Amersham-Pharmacia Biotech). Prehybridization and hybridization were performed at $65^{\circ} \mathrm{C}$ in $0.5 \mathrm{M} \mathrm{NaHPO}_{4} \mathrm{pH} 7.4,7 \%$ SDS, $1 \%$ skimmed milk. Conditions for the last wash was $0.2 \times$ SSC, $0.1 \%$ SDS at $65^{\circ} \mathrm{C}$.

\section{Construction of a cDNA library and identification of $S N P 1$ cDNA clones.}

Mycelium of $S$. nodorum isolate 171 was grown on cell wall inducing medium for 16,27 , or $40 \mathrm{~h}$ as described above. Six to eight grams of insoluble material (mycelium and plant cell walls) was frozen and comminuted in liquid nitrogen.
RNA was extracted with Trizol reagent (GibcoBRL Life Technologies) according to the manufacturer's instructions. Poly $\mathrm{A}^{+}$RNA was purified with the PolyAttract mRNA Isolation System IV (Promega). Five micrograms of Poly $A^{+}$RNA $(2.5 \mu \mathrm{g}$ from $16 \mathrm{~h}$ and $1.25 \mu \mathrm{g}$ each from 27 and $40 \mathrm{~h}$ ) was used for the cDNA synthesis with the ZAP cDNA synthesis kit (Stratagene, Amsterdam). Fifty nanograms of cDNA was ligated in the Uni-ZAP XR Vector Kit (Stratagene). $\lambda$ ZAPII recombinant DNA was packaged into a ZAP-cDNA Gigapack III Gold cloning kit (Stratagene). The primary library containing $4 \times 10^{6} \mathrm{PFU}$ was amplified.

\section{RT-PCR.}

RT-PCR was performed with RNA samples from 0.3 to 0.5 $\mathrm{g}$ of mycelium and from 0.5 to $1 \mathrm{~g}$ of leaf tissue with Trizol reagent (GibcoBRL Life Technologies) according to the manufacturer's protocol. After isopropanol precipitation, RNA was dissolved in $200 \mu \mathrm{l}$ of diethyl pyrocarbonate (DEPC)treated water. DNA was removed by treating $20 \mu \mathrm{g}$ of RNA with $3 \mathrm{U}$ of RNase-free DNase I (Promega) in the presence of $40 \mathrm{U}$ RNasine (Promega) for $30 \mathrm{~min}$ at $37^{\circ} \mathrm{C}$ in a volume of $40 \mu \mathrm{l}$. The reaction was stopped by adding $60 \mu \mathrm{l}$ of DEPCtreated water followed by a 1:1 ( $\mathrm{vol} / \mathrm{vol})$ phenol:chloroform and a chloroform partition prior to precipitation with isopropanol. The RNAs were resuspended at $1 \mu \mathrm{g} \mathrm{ml}^{-1}$ in DEPCtreated water.

The following RT was performed by first incubating $0.5 \mu \mathrm{g}$ of oligo(dT) ${ }_{15}$ and $2 \mu \mathrm{g}$ of RNA for $10 \mathrm{~min}$ at $70^{\circ} \mathrm{C}$, then immediately chilling on ice. Enzyme buffer, $2 \mu \mathrm{l}$ of $0.1 \mathrm{M}$ DTT, $1 \mu \mathrm{l}$ of $10 \mathrm{mM}$ NTPs, and $40 \mathrm{U}$ RNasine (Promega) was added to a final volume of $19 \mu$ then incubated $2 \mathrm{~min}$ at $42^{\circ} \mathrm{C}$. Two hundred U Superscript II (Gibco BRL Life Technologies) was added and incubated for $50 \mathrm{~min}$ at $42^{\circ} \mathrm{C}$. The reaction was stopped by heat inactivation for $10 \mathrm{~min}$ at $75^{\circ} \mathrm{C}$.

PCRs were performed with $1 \mu \mathrm{l}$ of reverse transcribed RNA, $200 \mu \mathrm{M}$ NTPs, $1.5 \mathrm{mM} \mathrm{MgCl}_{2}$, and 5 pmol of each primer in $25 \mu 1$. The amplification cycle was $94^{\circ} \mathrm{C} 4 \mathrm{~min}, 40 \times$ $\left(94^{\circ} \mathrm{C} 50 \mathrm{~s}, 58^{\circ} \mathrm{C} 60 \mathrm{~s}, 72^{\circ} \mathrm{C} 60 \mathrm{~s}\right), 72^{\circ} \mathrm{C} 5 \mathrm{~min}$. cDNAs were amplified with the $S N P 1$ specific primers F1b (GCACTTCA CAGACCTCCTCATTGCCCTC)-R11 (CAGCAACAAAGC TCGCAAGGCTGCTCTG), F12 (GAGTTCCCTGAGGGCG AGTTCCCCGAG)-R15 (TAGCTGATGGTGGAGCTGGTG GGGATG). As a positive control, the C-terminal region of an $S$. nodorum chitin synthase was amplified with CHSF (CCTT CGCTACACCTGCACACTTCTCATC)-CHSR (GACGGCC CAGAGGATGAATGTCAGGTAG) primers.

\section{GFP constructs and transformation.}

pUCGFP was constructed by introducing the 1.1-kb EcoRI fragment coding for the GFP protein from the plasmid pCRGFP2 (Spellig et al. 1996) into pUC19. SNP1 promoter was amplified by PCR with the primers SEPPY1 (ggcaGGATCCccacgatggc) and t11 (tgaagtCCATGGtgaat gaggctg). SEPPY1 was designed to introduce a BamHI site in the promoter at 1,140 bp from the ATG site and the NcoI site was removed at this location. 111 was designed to introduce an NcoI site at the ATG. The resulting amplified product was cut with BamHI and NcoI and ligated into the BamHI-NcoI cut pUCGFP. This gave an in-frame fusion at the ATG. The GFP protein obtained from this pUCpSNP1GFP construct is cytoplasmic as the SNP1 signal peptide was not included after the 
SNP1 promoter. A vector pUCpTUBAGFP to express constitutively GFP was also constructed, introducing the $-490-40$ promoter region of the $S$. nodorum tubulin gene (Cooley and Caten 1993) into the BamHI site of the pUCGFP vector. $S$. nodorum strain LAW 95 was co-transformed with one of the pUC GFP constructs and pAN7-1 (Punt et al. 1987) according to Cooley et al. (1988). Hygromycin-resistant transformants were screened for their ability to fluoresce when spores were germinated for $24 \mathrm{~h}$ in a basal salts medium containing $1 \%$ gelatin as sole carbon and nitrogen source. A strain expressing GFP constitutively was made by transforming the LAW 95 strain with pCRGFP2 and pAN7-1 plasmids.

\section{Confocal microscopy.}

Confocal microscopy was performed with a Leica TCS SP microscope. The light source was an argon laser. Excitation wavelength was $488 \mathrm{~nm}$ and detection was 510 to $520 \mathrm{~nm}$ (green channel) and 600 to $650 \mathrm{~nm}$ (red channel).

\section{ACKNOWLEDGMENTS}

We wish to acknowledge the invaluable help with enzyme purification from John Keon, IACR Long Ashton, supply of tritordeum cells and culture methods from P. A. Lazzeri, IACR, Rothamsted, and partial financial support from and interaction with Stephen Foster and Jane Dancer, AgrEvo UK Ltd. A. J. C. was supported by a BBSRC CASE studentship and L. B. by BBSRC grant no. 86/D09299.

\section{LITERATURE CITED}

Abraham, L. D., and Breuil, C. 1996. Isolation and characterisation of a subtilisin-like serine proteinase secreted by the sap-staining fungus Ophiostoma piceae. Enzyme Microb. Technol. 18:133-140.

Akashi, T., and Shibaoka, H. 1991. Involvement of transmembrane proteins in the association of cortical microtubules with the plasma membrane in tobacco BY-2 cells. J. Cell Sci. 98:169-174.

Ball, A. M., Ashby, A. M., Daniels, M. J., Ingram, D. S., and Johnstone, K. 1991. Evidence for the requirement of extracellular protease in the pathogenic interaction of Pyrenopeziza brassicae with oilseed rape. Physiol. Mol. Plant Pathol. 38:147-161.

Baker, C. S., and Mock, N. M. 1994. An improved method for monitoring cell death in cell suspension and leaf disc assays using Evans blue. Plant Cell Organ Cult. 39:7-12.

Bird, P. M., and Ride, J. P. 1981. The resistance of wheat to Septoria nodorum: fungal development in relation to host lignification. Physiol. Plant Pathol. 19:289-299.

Bradford, M. M. 1976. A rapid and sensitive method for the quantitation of microgram quantities of protein utilizing the principle of proteindye binding. Anal. Biochem. 72:248-254.

Carpita, N. C., and Gibeaut, D. M. 1993. Structural models of primary cell walls in flowering plants: consistency of molecular structure with the physical properties of the walls during growth. Plant J. 3:1-30.

Clarke, J. A., Lisker, N., Lamport, D. T. A., and Ellingboe, A. M. 1981. Hydroxyproline enhancement as a primary event in the successful development of Erysiphe graminis in wheat. Plant Physiol. 67:188-189.

Cooley, R. N., and Caten, C. E. 1993. Molecular analysis of the Septoria nodorum $\beta$-tubulin gene and characterisation of a benomyl-resistance mutation. Mol. Gen. Genet. 237:58-64.

Cooley, R. N., Shaw, R. K., Franklin, F. C. H., and Caten, C. E. 1988 Transformation of the phytopathogenic fungus Septoria nodorum to hygromycin B resistance. Curr. Genet. 13:383-389.

Cooper, R. M., Longman, D., Campbell, A., Henry, M., and Lees, P. E. 1988. Enzymic adaptation of cereal pathogens to the monocotyledonous primary wall. Physiol. Mol. Plant Pathol. 32:33-47.

Cornish-Bowden, A., and Eisenthal, R. 1974. Statistical considerations in the estimation of enzyme kinetic parameters by the direct linear plot and other methods. Biochem. J. 139:721.

D'Silva, I., Poirier, G. G., and Heath, M. M. 1998. Activation of cysteine proteases in cowpea plants during the hypersensitive response-a form of programmed cell death. Exp. Cell Res. 245:389-399.

Dahler, G. S., Barras, F., and Keen, N. T. 1990. Cloning of genes encoding extracellular metalloproteases from Erwinia chrysanthemi EC16. J. Bacteriol. 172:5803-5815.

Devereux, J., Haeberli, P., and Smithies, A. K. 1984. A comprehensive set of sequence analysis programs for VAX. Nucleic Acids Res. 12: 387-395.

Dow, J. M., Clarke, B. R., Milligan, D. E., Tang, J. L., and Daniels, M. J. 1990. Extracellular proteases from Xanthomonas campestris pv. campestris, the black rot pathogen. Appl. Environ. Microbiol. 56:29942998.

Dow, J. M., Davies, H. A., and Daniels, M. J. 1998. A metalloprotease from Xanthomonas campestris that specifically degrades proline/ hydroxyproline-rich glycoproteins of the plant extracellular matrix. Mol. Plant-Microbe Interact. 11:1085-1093.

Gebhard, W., Tschesche, H., and Frits, H. 1986. Biochemistry of aprotinin and aprotinin-like inhibitors. Pages 375-388 in: Proteinase Inhibitors. A. J. Barrett and G. Slavesen, eds. Elsevier Science, Amsterdam.

Hall, N., Keon, J. P. R., and Hargreaves, J. A. 1999. A homologue of a gene implicated in the virulence of human fungal disease is present in a plant fungal pathogen and is expressed during infection. Physiol. Mol. Plant Pathol. 55:69-73.

Heilbronn, J. Johnstone, D. J., Dunbar, B., and Lyon, G. D. 1995. Purification of a metalloprotease produced by Erwinia carotovora subsp. carotovora and the degradation of the potato lectin in vitro. Physiol. Mol. Plant Pathol. 47:285-292.

Hellmich, S., and Schauz, K. 1988. Production of extracellular alkaline and neutral proteases of Ustilago maydis. Exp. Mycol. 12:223-232.

Howard, S. P., and Buckley, J. T. 1985. Activation of the hole-forming toxin aerolysin by extracellular processing. J. Bacteriol. 163:336-340.

Joshi, B. N., Sainani, M. N., Bastawade, K. B., Gupta, V. S., and Ranjekar, P. K. 1998. Cysteine protease inhibitor from pearl millet: A new class of antifungal protein. Biochem. Biophys. Res. Commun. 246: 382-387.

Karjalainen, R., and Lounatmaa, K. 1986. Ultrastructure of penetration and colonisation of wheat leaves by Septoria nodorum. Physiol. Mol. Plant Pathol. 29:263-270.

Kieliszewski, M. J., Leykam, J. F., and Lamport, D. T. A. 1989. Trypsin cleaves lysylproline in a hydroxyproline-rich glycoprotein from Zea mays. Peptide Res. 2:246-248.

King, J. E., Cook, R. J., and Melville, S. C. 1983 A review of Septoria diseases of wheat and barley. Ann. Appl. Biol. 103:345-373.

Kivirikko, K. I., and Liesmaa, M. 1959. A colorimetric method for determination of hydroxyproline in tissue hydrolysates. Scand. J. Clin. Lab. Invest. 11:128-133.

Koiwa, H., Bressan, R. A., and Hasegawa, P. M. 1997. Regulation of protease inhibitors and plant defence. Trends Plant Sci. 2:379-384.

Kraut, J. 1977. Serine proteases: Structure and mechanisms of catalysis. Annu. Rev. Biochem. 46:331-358.

Laemmli, E. K. 1970. Cleavage of structural proteins during the assembly of the head of bacteriophage T4. Nature 227:680-685.

Lamport, D. T. A., and Miller, D. H. 1971. Hydroxyproline arabinosides in the plant kingdom. Plant Physiol. 48:454-456.

Lehtinen, U. 1993. Plant cell wall degrading enzymes of Septoria nodorum. Physiol. Mol. Plant Pathol. 43:121-134.

Lindstrom, J. T., and Belanger, F. C. 1994. Purification and characterisation of an endophytic fungal proteinase that is abundantly expressed in the infected host grass. Plant Physiol. 106:7-16.

Lorito, M., Broadway, R. M., Hayes, C. K., Woo, S. L., Noviello, C., Williams, D. L., and Harman, G. E. 1994. Proteinase inhibitors from plants as a novel class of fungicides. Mol. Plant-Microbe Interact. 7: 525-527.

Lusso, M., and Kuc, J. 1995. Increased activities of ribonuclease and protease after challenge in tobacco plants with induced systemic resistance. Physiol. Mol. Plant Pathol. 47:419-428.

Magro, P. 1984. Production of polysaccharide-degrading enzymes by Septoria nodorum in culture and during pathogenesis. Plant Sci. Lett. 37: 63-68.

Mauch, F., Mauch-Mani, B., and Boller, T. 1988. Antifungal hydrolases in pea tissue. II. Inhibition of fungal growth by combinations of chitinase and $\beta$-1,3-glucanase. Plant Physiol. 88:936-942.

Mazau, D., and Esquerré-Tugayé, M. T. 1986. Hydroxyproline-rich glycoprotein accumulation in the cell walls of plants infected by various 
pathogens. Physiol. Mol. Plant Pathol. 29:147-157.

Movahedi, S., and Heale, J. B. 1990a. Purification and characterisation of an aspartic proteinase secreted by Botrytis cinerea Pers ex. Pers in culture and in infected carrots. Physiol. Mol. Plant Pathol. 36:289302.

Movahedi, S., and Heale, J. B. 1990b. The roles of aspartic proteinase and endo-pectin lyase enzymes in the primary stages of infection and pathogenesis of the various host tissues by different isolates of $\mathrm{Bo}$ trytis cinerea Pers ex. Pers. Physiol. Mol. Plant Pathol. 36:303-324.

Murphy, J. M., and Walton, J. D. 1996. Three extracellular proteases from Cochliobolus carbonum: Cloning and targeted disruption of ALP1. Mol. Plant-Microbe Interact. 9:290-297.

Neurath, H. 1984. Evolution of proteolytic enzymes. Science 224:350357.

Newton, A. C., and Caten, C. E. 1988. Auxotrophic mutants of Septoria nodorum isolated by direct screening and by selection for resistance to chlorate. Trans. Br. Mycol. Soc. 90:99-207.

Osbourn, A. E., Scott. P. R., and Caten, C. E. 1986. The effect of host passaging on the adaptation of Septoria nodorum to wheat or barley. Plant Pathol. 35:135-145.

Packman, L. C. 1993. Protein chemical methods for molecular biologists. Methods Mol. Cell. Biol. 4:189-198.

Powers, J. C., and Harper, E. A. 1986. Inhibitors of serine proteases. Pages 55-152 in: Proteinase Inhibitors. A. J. Barrett and G. Slavesen, eds. Elsevier Science, Amsterdam.

Punt, P. J., Oliver, R. P., Dingemanse, M. A., Pouwels, P. H., and van den Hondel, C. A. M. J. J. 1987. Transformation of Aspergillus based on the hygromycin B resistance marker from Escherichia coli. Gene 56:117-124.

Raeder, U., and Broda, P. 1985. Rapid preparation of DNA from filamentous fungi. Lett. Appl. Microbiol. 1:17-20.

Raucher, M., Mendgen, K., and Deising, H. 1995. Extracellular proteases of the rust fungus Uromyces viciae-fabae. Exp. Mycol. 19:26-34.

Raz, R., Crétin, C., Puigdomenech, D., and Martinez-Izquierd, J. A 1991. The sequence of a hydroxyproline-rich glycoprotein gene from Sorghum vulgare. Plant Mol. Biol. 16:365-367.

Ries, S. M., and Albersheim, P. 1973. Purification of a protease secreted by Colletotrichum lindemuthianum. Phytopathology 63:625-629.

Robertson, B. 1984. An alkaline extracellular protease produced by $\mathrm{Cla}$ dosporium cucumerinum and its possible importance in the development of scab disease of cucumber seedlings. Physiol. Plant Pathol. 24:83-92.

Rypniewski, W. R., Hastrup, S., Betzel, C., Dauter, M., Dauter, Z., Papendorf, G., Branner, S., and Wilson, K. S. 1993. The sequence and $\mathrm{X}$-ray structure of the trypsin from Fusarium oxysporum. Protein Eng. 6:341-348.

Rypniewski, W. R., Perrakis, A., Vorgias, C. E., and Wilson, K. S. 1994. Evolutionary divergence and conservation of trypsin. Protein Eng. 7: 57-64.

Showalter, A. M. 1993. Structure and function of plant cell wall proteins. Plant Cell 2:1191-1200.

Sieber, T. 1989. Substrate utilization patterns of endophytic fungi of wheat seeds. J. Plant Dis. Prot. 96:627-632.

Smith, J. J., Muldoon, E. P., Willard, J. J., and Lamport, D. T. A. 1986. Tomato extensin precursors $\mathrm{p} 1$ and $\mathrm{p} 2$ are highly periodic structures. Phytochemistry 25:1021-1030.

Smithson, S. L., Paterson, I. C., Bailey, A. M., Screen, S. E., Hunt, B. A., Cobb, B. D., Cooper, R. M., Charnley, A. K., and Clarkson, J. M. 1995. Cloning and characterisation of a gene encoding a cuticledegrading protease from the insect pathogenic fungus Metarhizium anisopliae. Gene 166:161-165.

Spellig, T., Bottin, A., and Kahmann, R. 1996. Green fluorescent protein (GFP) as a new vital marker in the phytopathogenic fungus Ustilago maydis. Mol. Gen. Genet. 252:503-509.

Sreedhar, L., Kobayashi, D. Y., Bunting, T. E., Hillman, B. I., and Belanger, F. C. 1999 Fungal protease expression in the interaction of the plant pathogen Magnaporthe poae with its host. Gene 235:121129.

Steitz, T. A., and Shulman, R. G. 1982. Crystallographic and NMR studies of the serine proteases. Annu. Rev. Biochem. Biophys. 11: 419-444.

Stevens, C., Titarenko, E., Hargreaves, J. A., and Gurr, S. J. 1996. Defence-related gene activation during an incompatible interaction between Stagonospora (Septoria) nodorum and barley (Hordeum vulgare L.) coleoptile cells. Plant Mol. Biol. 31:741-749.

St. Leger, R. J., Joshi, L., Bidochka, M. J., Rizzo, N. W., and Roberts, D. W. 1996. Biochemical characterisation and ultrastructural localisation of two extracellular trypsins produced by Metarhizium anisopliae in infected insect cuticles. Appl. Environ. Microbiol. 62:1257-1264.

Tseng, T. C., and Mount, M. S. 1974. Toxicity of endopolygalacturonate trans-eliminase, phosphatidase and protease to potato and cucumber tissue. Phytopathology 64:229-236.

Vallélian-Bindschedler, L, Mösinger, E., Métraux, J.-P., and Schweizer, P. 1998. Structure, expression and localisation of a germin-like protein in barley (Hordeum vulgare L.) that is insoluble in stressed leaves. Plant Mol. Biol. 37:297-308.

van den Ackerveken, G. F. J. M., Vossen, P., and De Wit, P. J. G. M. 1993. The AVR9 race-specific elicitor of Cladosporium fulvum is processed by endogenous and plant proteases. Plant Physiol. 103:9196.

von Heijne, G. 1986. A new method for predicting signal sequence cleavage sites. Nucleic Acids Res. 14:4683-4690.

Walton, J. D. 1994. Deconstructing the cell wall. Plant Physiol. 104: 1113-1118.

Weber, G. F. 1922. II. Septoria diseases of wheat. Phytopathology 12 : 537-585.

Willis, J. W., Engwall, J. K., Leach, J. E., and Chatterjee, A. K. 1987. Extracellular protease of Erwinia carotovora subsp. carotovora: Characteristics and involvement in soft-rot pathogenesis. (Abstr.) Phytopathology 77:1736.

Zinkernagel, V., Reiss, F., and Wendland, M. 1988. Infection structures of Septoria nodorum in leaves of susceptible wheat cultivars. J. Plant Dis. Prot. 95:169-175. 